\title{
Anasınıfı Öğretmenleri ve İlkokul Yöneticilerinin 4+4+4 Eğitim Sisteminin Okul Öncesi Eğitime Yansımalarına ỉișkin Görüșleri
}

\author{
Songül GiREN ${ }^{1}$
}

\begin{abstract}
Öz: Bu araştırmada, anasınıfı öğretmenleri ve ilkokul yöneticilerinin (müdür ve müdür yardımcısı) 4+4+4 eğitim sisteminin okul öncesi eğitime yansımaları konusundaki görüşlerinin belirlenmesi amaçlanmıştır. Araştırma nitel bir araştırma olarak desenlenmiştir. Araştırmanın çalışma grubunu Adana ili Kozan ilçesi, Osmaniye ili Kadirli ilçesi ve Aksaray ili Merkez ilçesindeki ilkokullar bünyesinde görev yapan 8 yıl ve üzeri mesleki deneyime sahip 42 anasınıfı öğretmeni ve ilkokul yöneticisi (ilkokul müdürü ve müdür yardımclları) oluşturmuştur. Katılımcılar $4+4+4$ eğitim sistemini deneyimleyenler arasından amaçlı örnekleme yöntemiyle belirlenmiştir. Araştırmanın verileri hazırlanan standartlaştırılmış açık uçlu görüşme formu kullanılarak toplanmıştır. Verilerin analizinde içerik analizi ve betimsel analiz yöntemlerinden yararlanılmıştır. Katılımcıların görüşleri doğrultusunda yapılan içerik analizi sonucuna göre altı tema ortaya çıkmıştır. Bunlar, " $4+4+4$ eğitim sistemine ilişkin genel görüşler, $4+4+4$ eğitim sisteminin olumlu yönleri, $4+4+4$ eğitim sisteminin olumsuz yönleri, $4+4+4$ eğitim sisteminde yaşanan sorunlara ilişkin çözüm önerileri, 4+4+4 eğitim sisteminin okul öncesi eğitime etkileri ve okul öncesi eğitime yönelik düzenlemeler" şeklindedir. Araştırma sonuçlarına göre; okul öncesi eğitim 4+4+4 zorunlu eğitim sistemine dahil edilmeli, ilkokul eğitimi beş yıl olarak uygulanmalı, ilkokula erken yaşta (72 ay öncesinde) başlanmamalı, okul öncesi eğitim sistemi müfredat, yardımcı personel, alan uzmanı yönetici, materyal ve fiziksel ortam açısından desteklenmeli ve okul öncesi eğitim tüm çocuklar için daha ulaşılabilir (ücretsiz) olmalıdır. Araştırma bulgularına göre okul öncesi eğitim, 4+4+4 eğitim sistemi ile birlikte geri plana atılmıştır, bu nedenle geliştirme ve yaygınlaştırma çalı̧̧malarına önem verilmelidir.
\end{abstract}

Anahtar Sözcükler: Okul öncesi eğitim, 4+4+4 eğitim sistemi, Türk eğitim sistemi, Anasınıfı öğretmeni

\section{Kindergarten Teachers and Primary School Managers' Views About the Reflections on Preschool Education of the 4 + 4 + 4 Education System}

\begin{abstract}
In this research, it is aimed to determine the view of kindergarten teachers and primary school administrators about the reflections of $4+4+4$ education system on pre-school education. The research is designed as a qualitative research. The study group of the research consisted of 42 kindergarten teachers and primary school administrators (principals and vice principals) with 8 years or more professional experience working in the primary schools in Adana province Kozan district, Osmaniye province Kadirli district and Aksaray province Merkez district. Participants were determined by purposeful sampling method among those who experienced the $4+4+4$ education system. The research data were collected using the standardized open-ended interview form prepared. Content analysis and descriptive analysis methods were used in the analysis of the data. According to the results of the content analysis made in line with the opinions of the participants, six themes emerged. These are, "general views on the $4+4+4$ education system, the positive aspects of the $4+4+4$ education system, the negative aspects of the $4+4+4$ education system, the solution suggestions for the problems in the $4+4+4$ education system, effects of $4+4+4$ education system on pre-school education and arrangements for pre-school education". According to the research results; pre-school education should be included in the $4+4+4$ compulsory education system, primary school should be implemented as 5 years, primary school should not be started at an early age (72 months ago), the preschool education system should be supported in terms of curriculum, auxiliary personnel, field specialist manager, material and physical environment. Preschool education should be more accessible (free) for all children. According to the research findings, pre-school education has been pushed into the background with the $4+4+4$ education system; therefore, development and dissemination studies should be given importance.
\end{abstract}

Keywords: Pre-school education, 4+4+4 education system, Turkish education system, Kindergarten teacher 
Geçmişten günümüze bilim, sanat, teknoloji gibi birçok alanda bilginin hıla değişmesi, ülkelerin tüm sistemlerini etkilemekte ve onları zaman zaman bu sistemlerde değişiklik yapmaya yöneltmektedir. Sosyal devlet olma politikasının bir sonucu olarak tüm bireylere fırsat eşitliği çerçevesinde sunulması gereken en önemli kamu hizmeti olarak tanımlanan eğitimin, tüm yönlerini ve paydaşlarıyla ilgili konularını içeren eğitim sistemlerinde, sürekli yenilenen bilginin hızını yakalayabilmek için çok sık aralıklarla değişikliğe gidilmektedir (Aybek ve Aslan, 2015; Yılmaz, 2005). Eğitim, bilgi çağı olarak kabul edilen 21. yüzyılda değişimin ve dönüşümün birincil aktörü konumundadır. Toplumsal, siyasal, ekonomik ve teknolojik alanda gerçekleşen değişimlerin yanı sıra bireylerin, toplumun ve konunun diğer paydaşlarının gereksinimlerinin ve eğitim sisteminden beklentilerinin değişmesi, ülkeleri eğitim sistemlerinde veya eğitim programlarında yenilikler yapmaya zorlamaktadır (Cansoy, 2018; Örs, Erdoğan ve Kipici, 2013; Terzi, 2011). Erdoğan (2012, aktaran Memişoğlu ve İsmetoğlu, 2013).), Türk Eğitim Sistemindeki yenilik ve değişikliklerin gerekçesini okulların sanayi devrimi sonrasında ve bu devrimin etkisiyle oluşması, özel sektör ve kamu sektörü için yetiştirilecek personelin niteliğinin bilgi çağının gerektirdiği yeterliliklere sahip olmaması, bilgiyi üreten bir yaklaşım yerine ezberci, özgür düşünceyi engelleyen, bireysel farklılıkların göz ardı edildiği bir yaklaşıma dayalı olması, eğitimin hayat boyu devam eden bir süreci değil, kısa süreli ve dönemlik şekilde düzenlenmiş olması, bunun sonucunda zorunlu eğitim çağı dışında büyük bir insan topluluğunun yer alması ve bu topluluğun teknolojik değişimler karşısındaki yetersizliği olarak ifade etmektedir

Onuncu Kalkınma Planı Özel İhtisas Komisyonu Raporu'nda (2014-2018); yapılacak eğitim reformlarında öncelikle sistemdeki sorunların belirlenmesi, tüm ilgililerin görüşlerinin alınması ve yapılacak reformlar hakkında fikir alışverişinde bulunulması, pilot uygulamalarla aksayan yönlerin belirlenmesi, hizmet-içi eğitimlerle ve çeşitli programlarla güçlendirilmesi, reformların uygulanmasından sonra da izleme ve değerlendirme çalı̧̧maları ile etkinliğinin test edilmesi, bölgesel ve okuldan okula farklılaşan beşeri ve fiziksel altyapı sorunların giderilmesi, kamu ve özel sektör kaynaklarının çeşitlendirilerek artırılması ve eğitimde sosyal adaleti sağlayıcı politikalar belirlenmesi gerektiği belirtilmektedir (Kalkınma Bakanlığı, 2014). Ancak Türk Eğitim Sistemi ile ilgili belirlenen en önemli sorun, eğitim sisteminde yapılan değişikliklerin kapsamlı bir planlama yapılmadan gerçekleştirilmesi ve uygulayıcılarına yapılan değişikliklerin gerektiği şekilde açıklanamaması olarak ifade edilmektedir (Hareket, Erdoğan ve Dündar, 2016). Yine eğitim sisteminin, yapboz şeklinde deneme tahtasına dönüştürüldüğü ve eğitim politikalarının uygulanmasında bir süreklilik sağlanamadığı sıklıkla eleştirilen bir durumdur. Oysa eğitim reformlarının ortaya koyduğu sonuçların tespit edilmesi uzun yıllar gerektirmektedir (Kalkınma Bakanlığı, 2014). Hareket, Erdoğan ve Dündar (2016)'a göre Türk Eğitim Sisteminin sorunlarının çözülebilmesi için "eğitim politikacılarının Türk Eğitim Sistemini bilimsel veriler ışığında doğru analiz etmeleri ve tespit edilen sorunları zamanla, doğru adımlarla ve sistemli bir şekilde çözmeleri gerekmektedir" (s. 297).

Türk Eğitim Sistemi'nin yakın tarihine bakıldığında Milli Eğitim Bakanlığı (MEB) tarafından, 2005-2006 yılı eğitim öğretim döneminde, yetiştirilecek yeni insan modeline yönelik beklentileri karşılamak amacıyla ülke genelinde yapılandırmacı yaklaşım, öğrenci merkezli eğitim, çoklu zeka kuramı gibi kavramlara dayalı köklü bir eğitim felsefesi değişikliğine gidilmiştir (Başaran, 2016, Cansoy, 2018; Örs, Erdoğan ve Kipici, 2013; Terzi, 2011). Bu değişikliğe ilişkin Ankara, Bolu, Diyarbakır, Hatay, İstanbul, İzmir, Kocaeli, Samsun ve Van illerindeki 120 okulda deneme amaçlı uygulamalar başlatılmıştır. Yapılandırmacı yaklaşıma dayalı bu yeni programlar 1 yıllık pilot çalışmadan sonra 2005-2006 öğretim yılında ülke genelindeki tüm ilköğretim okullarında uygulamaya konmuştur (Başaran, 2016). Ancak yapılandırmacı yaklaşımı benimseyen ilköğretim programlarını değerlendirmeye yönelik sonuçlar göstermiştir ki; okulun örgüt ve yönetim yapısı içinde okul liderliği, vizyon, okul kültürü, sistemin girdi, süreç ve çıktı öğelerinde yapılandırmacı eğitim anlayışına yönelik herhangi bir olumlu değişim söz konusu değildir. Aksine yapılandırmacı yaklaşımla çatışan uygulamalara rastlamak daha olası bir durum olarak görülmektedir (Terzi, 2011). 2012-2013 eğitim öğretim yılına gelindiğinde ise daha önce 8 yıl olarak uygulanan zorunlu eğitim, herhangi bir pilot uygulama yapılmadan, konunun paydaşlarıyla tartışılmadan ve gerekli alt yapı hazırlıkları tamamlanmadan (Durmuşçelebi ve Bilgili, 2014) 6287 sayılı İlköğretim ve Eğitim Kanunu'nda değişikliğe gidilerek 4+4+4 eğitim sistemi ile 12 ylllık zorunlu kademeli eğitime dönüştürülmüş ve böylece eğitim süreci üç kademeye ayrılmıştır. Bu sisteme göre birinci 4 yıl ilkokul, (1-4. sınıf), ikinci 4 yıl ortaokul (5 - 8. sınıf) ve üçüncü 4 yıl lise 
(9 - 12. sınıf) eğitimi olarak düzenlenmiştir (MEB, 2012a). MEB (2012b), öğrencilerin yaş gruplarına veya bireysel farklılıklarına uygun olmayan kesintisiz 8 yıllık eğitim ile ülkemizin geleceği gençleri bilgi ve teknoloji çağının gerektirdiği beceri ve gereksinimlerle donatmanın mümkün olamayacağı gerekçesiyle eğitim sisteminde değişikliğe gidilerek $4+4+4$ kademeli zorunlu eğitim sistemine geçildiğini belirtmektedir. Bu değişikliğin iki temel amacı olduğu vurgulanırken bunlardan ilkinin, 12 yıllık zorunlu eğitim uygulamasıyla toplumun ortalama eğitim süresinin yükseltilmesi, ikincisinin ise kademeli bir yapıya kavuşturulması sonucu bireylerin ilgi, ihtiyaç ve yetenek alanlarına göre gerekli yönlendirmeyi yapabilmeyi sağlayıcı bir esnekliğe kavuşturulmasıdır (MEB, 2012b). Bu düzenleme ile ilgili yazılan bilimsel yazılarda çoğunluğu olumsuz olan farklı görüşler belirtilmektedir (Akbaşlı ve Üredi, 2014; Ankara Üniversitesi, 2012; Aybek ve Aslan, 2015; Aykaç, Arkan, Kabaran ve Bilgin, 2014; Aytaçlı ve Gündoğdu, 2018; Bahtiyar-Karadeniz, 2012; Boğaziçi Üniversitesi, 2012; Cerit, Akgün, Yıldız ve Soysal, 2014; Eğitimciler Birliği Sendikası (Eğitim-Bir-Sen), 2013; Epçaçan, 2014; ERG, 2012; Güven, 2012; Memişoğlu ve İsmetoğlu, 2013; Ortadoğu Teknik Üniversitesi, 2012; Örs, Erdoğan ve Kipici, 2013). Bunlardan birinde Güven (2012), yeni eğitim sisteminin eğitimsel gerçekler ve gereksinimleri karşılamanın aksine, hükümeti temsil eden kişilerin tercihleri doğrultusunda gerçekleştirilmiş olduğunu ifade etmektedir. Memişoğlu ve İsmetoğlu (2013), 4+4+4 eğitim sisteminin kademelendirilmesinin doğru olduğunu, ancak bu kademelendirmenin $5+3+4$ şeklinde yapılması gerektiğini belirtmektedir. Cerit ve diğerleri (2014) okul yöneticisi, öğretmen, veli, öğrenci ve basın yayın organlarının gerektiği şekilde bilgilendirilmemesinin ve bu nedenle toplumsal hazırbulunuşluğun sağlanamamasının sistem ve alt yapı sorunlarına yol açtığını belirtmektedir. Yeni düzenleme ile ilgili olarak üniversitelerin eğitim fakülteleri ve ilgili bölümleri, sivil toplum örgütleri, eğitim sendikaları, eğitimle ilgili dernekler ve çeşitli kurum/kuruluşlar da görüş belirtmişlerdir. Bunlardan Boğaziçi Üniversitesi (2012) yayınladığı görüşünde;

Yeni taslakta 1'inci sınıf yaşı bir yıl öne alınmaktadır. Böylece, 60-72 ay çocukları, okulöncesi eğitime değil, 1'inci sınıfa alınacaktır. Bu uygulama pedagojik açıdan sakıncalıdır. Bu yaş çocukları, daha somut işlemler dönemine geçmediği için 1'inci sınıf becerileri arasında bulunan okuma-yazma, basit sayısal değerlendirme ve işlemleri yapabilecek bilişsel düzeyde değildir. Müfredatı değiştirmek ise 1'inci sınıfta etkinlikle verebildiğimiz bu becerileri bir yıl erteleme durumunu yaratacak ve ilköğretimin 1'inci sınıfına ait olmayan okulöncesi becerileri bu sınıfa taşıyacaktır. O zaman, içerik açısından model 1+3+4+4 haline gelecektir. Böyle bir sistem oluşumu, bilimsel açıdan sakıncalı olduğu gibi aynı zamanda hiç bir ülkede bulunmayan anlaşılmaz bir bölünmeyi oluşturacaktır.

Ankara Üniversitesi (2012) tarafından sunulan görüşlerde;

Önerilen 4+4+4 modeli eğitim hakkına erişimi engellemektedir. 1739 sayılı Milli Eğitim Temel Kanunu'na göre temel eğitim, her Türk vatandaşının yasal hakkıdır ve devlet eliyle parasız verilir. Bu eğitim, Milli Eğitim Temel Kanunu'nun 4., 5., 6., 7., 8., 9. ve 12. Maddelerinde ifade edilen "genellik ve eşitlik", "ferdin ve toplumun ihtiyaçları", "yöneltme", "eğitim hakkı", "fırsat ve imkan eşitliği", "laiklik" ve "süreklilik" ilkelerine uygun olmalıdır. Oysa kanun teklifi ile farklı toplumsal gruplar ve tabakalardan çocukların eğitim hakkı engellenmekte, eğitimde eşitlik ilkesi zedelenmektedir. Kanun teklifi, 8 yıllık temel eğitimi fiilen 4 yıla indirerek kız çocuklarının, yoksul çocukların, köy çocuklarının ve engelli çocukların üst öğrenime devam etme olanaklarını ortadan kaldırmaktadır. Tasarı, çocuk işçiliğini, toplumsal cinsiyet eşitsizliği ve ayırımcılığı, sınıfsal ayrışmayı, köy-kent kutuplaşmasını teşvik etmekte, çocukların toplumsallaşarak bütünsel ve çok yönlü gelişiminin önünü kapatmaktadır.

Ortadoğu Teknik Üniversitesi (2012) tarafından sunulan görüşlerde;

2005 yılından itibaren uygulanan öğretim programları, 1. sınıftaki öğrencilerin okula başlama yaşının 6 yaş olarak değerlendirilmesi ile oluşturulmuştur. Okula başlama yaşının 5 yaşa indirilmesi tüm derslere ait programlarda köklü değişikliklere gidilmesini, kitapların ve kılavuzların yeniden düzenlenmesini ve özellikle sınıf öğretmenlerinin 5 yaş özelliklerine göre bir öğretim yapmasını gerektirecektir. Ancak 4+4+4 sistemine önümüzdeki öğretim yılından itibaren başlanacağı yönündeki ifadeler, programlar yeni yapılanmaya göre değiştirilmeden, pilot uygulamalar yapılmadan ve öğretmenler bu konuda hizmet içi eğitim almadan başlanacağını göstermektedir. Böylesine köklü bir değişiklik var olan eğitim sistemi sorunlarını daha da çözümsüz kılacaktır.

Literatürde 4+4+4 eğitim sisteminin yürürlüğe girdiği ilk günlerde dile getirilen bu eleştirel görüşleri destekleyici ya da reddedici sonuçların elde edildiği araştırmalar, 4+4+4 kademeli zorunlu eğitim sistemi ile ilgili uygulamaya yönelik birçok sorunla birlikte konunun farklı yönlerini ortaya koymaktadır (Anne Çocuk Eğitim Vakfı (AÇEV) ve Eğitim Reformu Girişimi (ERG), 2013; Aykaç ve diğerleri, 2014; Aybek ve Aslan, 2015; Aytaçlı ve Gündoğdu, 2018; Akbaşlı ve Üredi, 2014; Bahtiyar-Karadeniz, 2012; Cerit, Akgün ve diğerleri, 2014; Eğitim-Bir-Sen, 2013; Epçaçan, 2014; ERG, 2012; Memişoğlu ve İsmetoğlu, 2013; Örs, Erdoğan ve Kipici, 2013). $\mathrm{Bu}$ araştırmalara göre; her ne kadar uygulamada tüm okullar için planlandığı gibi olmasa da, ilköğretim 
okullarının ayrıştırılarak 6-14 yaş gibi birbirinden çok farklı yaş gruplarının ayrı okullarda eğitim alacak olması olumlu karşılanmıştır (Doğan, Uğurlu ve Demir, 2014; Eğitim-Bir-Sen, 2013; Epçaçan, 2014). İlkokulların beş yıldan dört yıla inmesiyle sınıf öğretmenleri açısından norm fazlası öğretmen sorunu oluşmuştur (Eğitim-Bir-Sen, 2013; Doğan, Uğurlu ve Demir, 2014; Durmuşçelebi ve Bilgili, 2014). Bu sorun da sınıf öğretmenlerine branş değişikliğiyle ortaöğretime geçiş hakkı verilerek çözülmeye çalışılmıştır. 60-66 aylık çocukların okula başlaması veliler, öğretmenler ve okul yöneticileri tarafından en çok tartışılan konu olmuş ve çoğunluğu tarafından olumsuz bir değişiklik olarak ifade edilmiştir. Okula başlama yaşının yeniden 72 ay ve üzeri olması gerektiği ifade edilmiştir (Arı, 2014; Doğan, Uğurlu ve Demir, 2014; Eğitim-Bir-Sen, 2013; Epçaçan, 2014; Memişoğlu ve İsmetoğlu, 2013). Bu yaş grubu çocuklarda başta okula uyum sorunları olmak üzere çok fazla sorunla karşılaşıldığı ifade edilmiştir. Haftalık ders saatinin artırılması, $4+4+4$ eğitim sistemini destekleyenler tarafından bile eleştirilerek beşinci sınıf öğrencilerinin günlük 7-8 saatlik ders programı için hazır olmadıkları belirtilmiştir (Durmuş̧̧elebi ve Bilgili, 2014; Eğitim-Bir-Sen, 2013; Epçaçan, 2014). Dini içerikli ya da yabancı dil, matematik gibi seçmeli derslerin programda yer alması eğitimde demokratik taleplerin dikkate alınması adına olumlu bir gelişme olarak değerlendirilmiş̧ir (Doğan, Uğurlu ve Demir, 2014; Eğitim-Bir-Sen, 2013; Epçaçan, 2014). 2010 yllından itibaren başlayan uygulama ile bütün okullar Anadolu liseleri haline getirilmiştir. Sınavla sınırlı sayıda öğrenci alan bu okullar ise; meslek liselerinde sınıf mevcudunun kalabalıklaşmasına neden olmuştur. Eğitimin 12 yıla çıkarılması, meslek liselerinde okula devamsızlığın artması ve okulu terk oranlarının yükselmesi olarak yansımıştır (Eğitim-Bir-Sen, 2013).

4+4+4 eğitim sisteminin uygulamaya konmasıyla 2012-2013 eğitim öğretim yılında 30 Eylül itibari ile 60 ay ve üzeri çocuklar ilkokul eğitimine alınmaya başlamıştır (Pekdoğan ve Karamustafaoğlu, 2015). 4+4+4 uygulamasından önce okul öncesi eğitimin hitap ettiği çocuklar 36-72 ay grubunda iken, $4+4+4$ eğitim sistemi ile birlikte üst sınırda 59 aya doğru bir gerileme olmuştur (Pekdoğan ve Karamustafaoğlu, 2015). Bu durum beraberinde pek çok tartışmayı getirmiştir. Okul öncesi eğitimin zorunluluktan çıkarılması ve bunun ilkokula hazırlık açısından alt sosyo-ekonomik düzeyden gelen çocuklar aleyhine olması, çocukların ilkokula bir yıl erken başlamasının gelişim özellikleri açısından bilimsel gerçeklere uygun olmaması, bütün yönleriyle hızlı bir gelişimin söz konusu olduğu çocukluk yıllarında çocuklar arasındaki üç ay gibi bir sürenin bile çok önemli olduğu gerçeği göz önüne alındığında birinci sınıfta 60 ve 72 aylık çocukların bir arada eğitilmelerinin zihinsel, bedensel, sosyal - duygusal ve kişilik özellikleri bakımından birbirinden oldukça farklı olan çocuklar açısından sakıncalı olduğu ve öğretmene de ek sorumluluk getireceği şeklinde eleştiriler sunulmuştur (Ankara Üniversitesi, 2012; Boğaziçi Üniversitesi, 2012; ODTÜ, 2012). Ayrıca 60 aylık çocukların birinci sınıfa kayıt yaptırmasıyla akranlarıyla aralarında neredeyse 24 aylık fark bulunan çocukların aynı sınıfta başarı için birbirleriyle mücadele etmek zorunda kalacağı belirtilmiştir (Durmaz, 2020). 60 aylık çocukların ilkokula başlamasıyla ilgili 10 Temmuz 2019 tarih ve 30827 sayılı resmi gazetede yayımlanan Resmi Gazete (2019), Okul Öncesi ve İlköğretim Kurumları Yönetmeliği'nde Değişiklik Yapılmasına Dair Yönetmelik'te yapılan değişiklikle geri adım atılmış;

Madde 7 - a) İlkokulların birinci sınıfına, kayıtların yapıldığı yılın eylül ayı sonu itibarıyla 69 ayını dolduran çocukların kaydı yapılır. Ayrıca 66, 67 ve 68 aylık çocuklardan velisinin yazılı isteği bulunanlar da ilkokul birinci sınıfa kaydedilir. b) Okul müdürlükleri, yaşça kayıt hakkını elde eden çocuklardan 69,70 ve 71 aylık olanları velisinin yazılı talebi bulunması halinde okul öncesi eğitime yönlendirir veya kayıtlarını bir yıl erteler.

şeklinde değiştirilerek düzeltilmeye çalışılmıştır.

Okul öncesi eğitim, ilkokul çağına gelmemiş çocukların bedensel, zihinsel, sosyal, duygusal, psikomotor ve öz bakım becerileri açısından okula uyum ve okul olgunluğunu sağlayarak, ilkokula hazır hale gelmesinde, iyi alışkanlıklar kazanarak kişilik gelişiminde ve topluma etkin bir birey olarak katılmasında çok önemli bir rol oynamaktadır. Okul öncesi eğitim, eğitim sisteminin ilk ve en önemli basamağı, deyim yerindeyse gömleğin ilk düğmesi gibidir. Tüm bireyler için eşit, ulaşılabilir ve kaliteli eğitimin sunulabilmesi bu ilk düğmenin doğru iliklenmesine bağlıdır (AÇEV ve ERG, 2013). 4+4+4 eğitim sisteminden önce okul öncesi eğitime devam eden 60-72 ay arası çocukların ilkokula başlaması ile ilgili yapılan araştırmalarda; bu yaştaki çocukların küçük kas becerileri (Boz ve Yıldırım, 2014), tuvalet temizliği ve hijyen gibi özbakım becerilerinin kazanımı açısından daha fazla desteğe ihtiyaç duyduğu, bu nedenle ek temizlik materyali ve temizlik elemanı gereksinimi doğduğu (Memişoğlu ve İsmetoğlu, 2013), öğretmenlerin eğitim sisteminin getirdiği yeniliklere 
uyum sağlama konusunda; çocukların ise gelişimsel açıdan yaşadıkları yetersizlikler nedeniyle zorluklar yaşadığ $\breve{~ b u ~ n e d e n l e ~} 4+4+4$ eğitim sisteminin okul öncesi eğitimi olumsuz etkilediği (Pekdoğan ve Karamustafaoğlu, 2015) belirtilmektedir. Çocukların dikkat dağınıklığı, ebeveynden/anneden ayrılma korkusu yaşadıkları ve bazı etkinliklerde ince motor gelişimlerinde yetersizlikler nedeniyle zorlandıkları, 66 ay ila 81 ay arasında değişen karma yaş gruplu sınıflarda eğitim kalitesinin düştüğü (Pekdoğan ve Karamustafaoğlu, 2015), ilkokul eğitimine 60-66 aylar arasında başlayanların 67-71 ve 72-84 aylar arasında başlayan çocuklara göre akademik başarılarının daha geride olduğu (Memişoğlu ve İsmetoğlu, 2013; Özarslan, 2014; Turan, 2018) tespit edilmiştir. Bu durumun ilkokula erken başlamayı okul olgunluğu (Bayat, 2015) ve hazırbulunuşluk açısından bir dezavantaja dönüştürdüğü (Turan, 2018) görülmüştür. 60-66 aylık olarak ilkokula başlayanların, ilk okuma-yazma öğrenme ve okuduğunu anlamada 72 ay ve üzeri gibi ileri yaşta başlayan çocuklara göre daha başarısız oldukları (Bayat, 2015; Tutal, 2013) ilkokula erken başlayan çocukların diğerlerine göre çok daha fazla sosyal-duygusal uyum sorunları yaşadıkları ifade edilmiştir (Bayat, 2015; Dirlik, 2014; Memişoğlu ve İsmetoğlu, 2013; Turan, 2018; Yoleri ve Tanış, 2014). Dağ (2017), 60-66 aylık başlayanların ve 69 ay ve üzerin başlayanların dördüncü sınıftaki akademik başarılarını karşılaştırmış ve ilkokula erken başlamanın çocukların gelecekteki akademik başarılarını da etkilediğini belirtmiştir. Gedik (2015), ilkokula erken başlayan çocuklar arasında okul öncesi eğitim almış olmanın okula uyum sağlamada etkin rol oynadığını belirtmiştir. İlkokul öğretmenleri, 60 aylık çocukların ilkokula başlaması fikrine sıcak bakmamaktadır. Ayrıca okula başlama için çocuğun takvim yaşına değil, gelişimsel olgunluğuna bakılması ve ilkokula başlayacak 60-66 aylık çocukların mutlaka okul öncesi eğitim alması gerektiğini belirtmektedir (Aslan, 2014).

Eğitim sistemlerinde hedeflenen kaliteli eğitim seviyesine ulaşmanın, bu sistemi oluşturan paydaşlar ile yapılacak bilimsel araştırmalar ve paylaşımcı yaklaşımlarla sağlanabileceği belirtilmektedir (Hareket, Erdoğan ve Dündar, 2016). Ancak literatürde yeni eğitim sisteminin okul öncesi eğitime bakan yönünü ele alan, anasınıfı öğretmenlerinin ve ilkokul yöneticilerinin bu konudaki görüşlerinin alındığı, eğitim sisteminin okul öncesi eğitimi ilgilendiren boyutuyla uygulamadaki eksikliklerinin belirlendiği herhangi bir çalışmanın bulunmadığı görülmüştür. Bu noktadan hareketle anasınıfı öğretmenlerinin ve ilkokul yöneticilerinin yeni eğitim sistemi ile ilgili yaşamış oldukları sorunların tespit edilmesi ve bu sorunlara yönelik geliştirecekleri çözüm önerilerinin belirlenmesi araştırılmaya değer bir konu olarak görülmüştür. Ayrıca anasınıfı öğretmenlerinin $4+4+4$ kesintili zorunlu eğitim sistemi ile ilgili yaşamış oldukları sorunların tespit edilmesinin ve bu sorunlara yönelik geliştirdikleri çözüm önerilerinin belirlenmesinin literatüre önemli katkılar sağlayacağı düşünülmektedir.

\section{Araştırmanın Amacı}

Bu araştırmanın amacı, ilkokullar bünyesindeki anasınıflarında görev yapan anasınıfı öğretmenlerinin ve ilkokul yöneticilerinin (müdür ve müdür yardımcısı) 4+4+4 kesintili zorunlu eğitim sistemi ile ilgili görüşlerini (olumlu/olumsuz), yaşadıkları sorunları ve bu sorunlara yönelik çözüm önerilerini belirlemektir. Bu amaç çerçevesinde aşağıdaki sorulara cevap aranmıştır:

1. Anasınıfı öğretmenleri ve ilkokul yöneticilerinin $4+4+4$ kesintili zorunlu eğitim sistemi hakkındaki genel fikirleri nelerdir?

2. Anasınıfı öğretmenleri ve ilkokul yöneticilerinin $4+4+4$ kesintili zorunlu eğitim sistemine yönelik olumlu (yararlı) bulduğu yönler nelerdir?

3. Anasınıfı öğretmenleri ve ilkokul yöneticilerinin $4+4+4$ kesintili zorunlu eğitim sistemine yönelik olumsuz (karşılaştıkları sorunlar) bulduğu yönler nelerdir?

4. Anasınıfı öğretmenleri ve ilkokul yöneticilerinin görüşlerine göre $4+4+4$ kesintili zorunlu eğitim sisteminin okul öncesi eğitimi ve anasınıflarını etkileyen yönleri nelerdir?

5. Anasınıfı öğretmenleri ve ilkokul yöneticilerinin görüşlerine göre $4+4+4$ kesintili zorunlu eğitim sistemi ile ilgili ne tür değişiklikler yapılmalıdır? Neden?

6. Anasınıfı öğretmenleri ve ilkokul yöneticilerinin $4+4+4$ kesintili zorunlu eğitim sisteminde karşılaştıkları sorunlara ilişkin çözüm önerileri nelerdir? 


\section{Yöntem}

Bu bölümde araştırmanın modeli, çalışma grubu, veri toplama süreci ve verilerin analizine ilişkin bilgilere yer verilmiştir.

\section{Araștırmanın Modeli}

4+4+4 kesintili zorunlu eğitim sisteminin okul öncesi eğitime yansımalarının anasınıfı öğretmenleri ve ilkokul yöneticilerinin görüşleri doğrultusunda incelendiği bu araştırmada nitel araştırma yöntemi kullanılmıştır. Nitel araştırma; doküman analiz etme, katılımcılarla görüşme yapma, olay veya duruma ilişkin gözlem yapma gibi nitel veri toplama yöntemlerinin kullanıldığı, insana özgü algı ve olayların gerçek ortamında bütünsel olarak ortaya konması amacıyla yürütüldügü bir araştırma sürecidir (Yıldırım ve Şimşek, 2013). Bir başka tanımlamada ise nitel araştırmanın, araştırmacının değişkenlerin kontrol altında tutulduğu laboratuvar ya da akademi ortamında değil, içinde yaşadığımız gerçek dünyadaki olaylara, durumlara ve kavramlara ilişkin yapılan gözlemler ve görüşmeler sonucu ortaya çıkarıldığı belirtilmektedir (Patton, 2014). Baltacı (2019), nitel araştırmanın genelleme yapmak yerine bilginin derinliklerine ulaşmayı hedeflediğini, insana ait kişisel özeliklerin farklılı̆̆ına ve derinliğine yöneldiğini belirtmektedir. Creswell (2013) nitel araştırmanın, araştırma verilerinin yorumlanması temeline dayanan bir araştırma olduğunu ve bu araştırmalarda araştırmacıların katılımcılarla derinlemesine bir deneyim ve süreklilik içerisinde olduklarını belirtmektedir. Araştırmada, eğitim sisteminin uygulamaya dönük faaliyetlerinin planlanmasında ve yürütülmesinde aktif görev alan ilkokul yöneticilerinin ve anasınıfı öğretmenlerinin ve $4+4+4$ eğitim sistemine yönelik deneyimleri nitel araştırma yöntemi kullanılarak incelenmeye çalışılmıştır. Araştırmada nitel araştırma desenlerinden olgubilim olarak da bilinen, fenomenolojik araştırma deseni kullanılmıştır. Bu tür araştırmalarda bir fenomen vurgulanarak katılımcıların bu fenomen ile ilgili düşünceleri, fenomene yönelik bakış açıları, nasıl anlamlar yükledikleri, fenomen ile ilgili yaşantısal tecrübeleri ve bu tecrübelerini nasıl tanımladıkları üzerine yoğunlaşılır (Tekindal ve Uğuz Arsu, 2020). Onat Kocabıyık (2016), fenomenolojik araştırmalarda amacın, araştıılan olgunun temelindeki ortak anlamları belirleyerek katılımcıların yaşamış olduğu deneyimlerinden oluşan dünyayı anlamak olduğunu belirtmektedir. Fenomenolojik araştırmalarda incelenen olgular, günlük hayatımızda sıklıkla karşılaşabileceğimiz durumlar, yaşamsal deneyimler, olaylar, duygular, düşünceler, kavramlar veya algılar olabilir (Tekindal ve Uğuz Arsu, 2020; Yıldırım ve Şimşek, 2013). Fenomenoloji yaklaşımını diğer nitel araştırma desenlerinden ayıran en temel özellik "ortak deneyimlerin özünü oluşturduğu" düşüncesine dayandırılmasıdır. Fenomenoloji, katılımcılar tarafından ortaklaşa deneyimlenmiş bir fenomen yoluyla oluşturulan algıların özünü ve birincil anlamlarını betimlemek olarak ifade edilmektedir (Tekindal ve Uğuz Arsu, 2020). Bu araştırmada da anasınıfı öğretmenleri ve ilkokul yöneticilerinin $4+4+4$ eğitim sistemi fenomenine ilişkin deneyimleri, düşünceleri ve algıları betimlenmeye çalışılmıştır.

\section{Çalışma Grubu ve Demografik Özellikleri}

Bu araştırmada 4+4+4 eğitim sisteminin daha önce uygulanan 8 yıllık eğitim sistemine göre avantajlı veya dezavantajlı yönlerini var olan sorunları ve olası çözüm önerileriyle birlikte net bir şekilde ortaya koyabilecekleri düşünüldüğünden, eğitim faaliyetlerinin uygulanmasından birinci derecede sorumlu olan anasınıfı öğretmenleri ve ilkokul yöneticileri katılımcı olarak seçilmiştir. Adana ili Kozan ilçesi, Osmaniye ili Kadirli ilçesi ve Aksaray ili Merkez ilçesinden amaçlı örnekleme yoluyla ulaşılan 42 anasınıfı öğretmeni ve ilkokul yöneticisi araştırmanın çalışma grubunu oluşturmuştur. Katılımcıların araştırmada incelenen $4+4+4$ eğitim sistemi ile daha önceki eğitim sistemini ve uygulamalarını karşılaştırarak görüşlerini aktarabilmeleri için, katılımcılarda 8 yıl ve üzeri mesleki kıdeme sahip olma şartı aranmıştır. 4+4+4 eğitim sistemini deneyimlemiş olanların araştırmaya dahil edilebilmesi için amaçlı örnekleme yöntemi kullanılmıştır. Araştırmaya katılan anasınıfı öğretmenlerinden 1'i (\%4,35) erkek 22'si (\%95,65) kadındır. İlkokul yöneticilerinin tamamı erkektir. İlkokul yöneticilerinin 8'i $(\% 42,11)$ müdür yardımcısı, 11'i $(\% 57,89)$ müdürdür. Araştırmaya katılan okul yöneticileri ve anasınıfı öğretmenlerinin mezun oldukları üniversite bilgilerine bakıldığında; Çukurova Üniversitesi 3 (\%7,14), Selçuk Üniversitesi 6 (\%14,29), Afyon Kocatepe Üniversitesi 1 kişi (\%2,38), Anadolu Üniversitesi 9 kişi (\%21,43), Gazi Üniversitesi 7 kişi (\%16,67), Sakarya 
Üniversitesi 1 kişi (\%2,38), Niğde Üniversitesi 3 kişi $(\% 7,14)$, Mustafa Kemal Üniversitesi 2 kişi $(\% 4,76)$, Atatürk Üniversitesi 3 kişi $(\% 7,14)$, Karadeniz Teknik Üniversitesi 1 kişi $(\% 2,38)$, Uludağ Üniversitesi 1 kişi $(\% 2,38)$, Kırşehir Ahi Evran Üniversitesi 1 kişi $(\% 2,38)$, Malatya Üniversitesi 1 (\%2,38), Ağrı İbrahim Çeçen Üniversitesi 1 kişi (\%2,38), 19 Mayıs Üniversitesi 1 kişi (\%2,38), Çanakkale 18 Mart Üniversitesi 1 kişi $(\% 2,38)^{\prime}$ dir. Katılımcların mesleki kıdemlerine göre gruplandığında 10-15 yıl arasında olan 19 kişi $(\% 45,24)$, 16-20 yıl arasında olan 7 kişi $(\% 16,67), 21-25$ yıl arasında 8 kişi (\% 19,05), 26 yıl ve üzerinde olan 8 kişi $(\% 19,05)$ olduğu görülmüştür.

\section{Veri Toplama Süreci}

Araştırmaya katılım gönüllülük esası dikkate alınarak gerçekleştirilmiştir. Görüşmelerin amacı, 4+4+4 eğitim sisteminin okul öncesi eğitime yansımaları hakkında anasınıfı öğretmenlerinin ve ilkokul yöneticilerinin görüşlerini ortaya koymaktır. Yıldırım ve Şimşek (2013), açık uçlu soruların araştırmacıya araştırma sorularının çok daha fazla ayrıntılı irdelenmesi imkânı verdiğini, esneklik sağladığını, keşfetme ve elde edilen verilerden hareketle kuram oluşturma fırsatı sunduğunu belirtmektedir. Bu nedenle araştırmanın amacını gerçekleştirmede sağlayacağı avantajlar nedeniyle eğitimle ilgili araştırmalarda sıklıkla kullanılan görüşme stratejilerinden açı uçlu standartlaştırılmış görüşme tekniği kullanılmıştır. Standartlaştırılmış açık uçlu görüşmede "soruların tam olarak sırası ve tarzı önceden belirlenir. Görüşme yapılan tüm kişilere aynı temel sorular aynı sıra ile sorulur. Sorular tam anlamıla açık uçlu bir formatta ifade edilir" (Büyüköztürk, Kılıç Çakmak, Akgün, Karadeniz ve Demirel, 2009). Verilerin toplanması sürecinde Covid 19 salgını devam ettiği için ilkokul yöneticileri ile okullarda yüz yüze görüşmeler yapılmıştır. Yöneticilerle yapılan görüşmelerde önce araştırmanın amacına yönelik bilgiler verilmiştir. Katılımcıların kişisel bilgilerinin gizli tutulacağı ve araştırmada hiçbir şekilde kullanılmayacağı belirtilmiştir. Her bir yönetici ile yapılan görüşme 15-20 dakika arasında sürmüştür. Görüşme soruları tüm katılımcı yöneticilere aynı sıra ile sorulmuş ve alınan cevaplar, ses kaydı alınmasına izin verilmemesi nedeniyle araştırmacı(lar) tarafından not edilmiştir. İlkokul yöneticileri sorulara genel olarak kısa cevaplar vermeyi tercih etmiştir. Salgın sürecinde okulların eğitime devam edememesi nedeniyle anasınıfı öğretmenlerine okulda doğrudan ulaşılamamıştır. Anasınıfı öğretmenlerinin bir kısmına okul yöneticileri aracılı̆̆ıyla ulaşılmış ve hangi günlerde okula geldikleri sorulmuştur. O günler belirlenerek bu öğretmenlerle okulda görüşme yapılmıştır. Görüşmeler sessiz bir ortamda, 15 ila 20 dakika arasında sürmüştür. Öğretmenlerin sorulara verdikleri cevaplar görüşme formuna not edilmiştir. Anasınıfı öğretmenlerinin bir kısmına ise sosyal medya platformlarından ulaşılmaya çalışılmıştır. Googleforms üzerinden oluşturulan ve araştırmanın amacını açıklayan bir bilgi formu ile anasınıfı öğretmenlerinden araştırmaya katılmak için gönüllü olanlarla iletişim kurulmuştur. Telefon numarası ile araştırmaya katılmak istediğini belirterek geri dönüş yapan öğretmenler çalışma grubuna alınmıştır. Bu öğretmenler telefon ile aranarak görüşme yapılmıştır. Görüşme sorularına verdikleri cevaplar araştırmacı(lar) tarafından not edilmiştir. İlkokul yöneticileri gibi öğretmenlerin de çoğunluğu görüşmelerde uzun ve açıklayıcı cevaplar yerine kısa cevaplar vermeyi, bazı sorulara ise cevap vermemeyi tercih etmiştir. Katılımcılar, bazı sorulara öğretmen veya yönetici olarak değerlendirmek yerine anne-baba bakış açısıyla cevaplar vermişlerdir. Görüşmeler sonucunda elde edilen bilgiler, verilerin analizi aşamasında içerik analizi yapılarak analiz edilmiştir.

Araştırmada kullanılan görüşme formunun hazırlanmasında alan yazındaki yapılmış benzer araştırmalardan yararlanılmıştır. Ayrıca alan uzmanlarıyla fikir alış-verişinde bulunulmuştur. Taslak görüşme formu hazırlandıktan sonra, kapsam geçerliliği için okul öncesi eğitim alanından üç uzmanın görüşüne başvurulmuştur. Uzman görüşleri doğrultusunda "İçerik Geçerliliği Oranı (content validity ratio, CVR)" (Lawshe, 1975) hesaplanmıştır. Sağlık hizmetleri, eğitim, organizasyonel gelişim, kişisel psikolojisi ve pazar araştırması alanlarında içerik(kapsam) geçerliliğini belirlemek ve ölçmek için yaygın olarak kullanılan Lawshe'nin yöntemi (Lawshe, 1975), bir ölçme aracındaki öğelerin, ilgili konu alanı uzmanlarınca tek tek incelenmesini ifade etmektedir (Ayre ve Scally, 2014). Yani görüşme formu için belirlenen soruların her birinin alan uzmanlarınca değerlendirilmesidir. Lawshe (1975, aktaran Ayre ve Scally, 2014), her soru için hesaplanan CVR değerinin -1 (mükemmel uyumsuzluk) ile +1 (tam uyum) arasında değişen bir değer alabildiğini, konu alanı uzmanlarının sorularla ilgili hemfikir olma seviyesinin \%50'den fazla olmasının yani 
sıfırın üzerindeki CVR değerlerinin konu alanı uzmanlarınca yarısından fazlasının bir öğeyi esas olarak kabul ettiğini gösterdiğini belirtmektedir. Kısacası CVR değerinin 0'ın üzerinde değer alması ve +1 'e yakın olması o sorunun içerik/kapsam geçerliğini sağladığı şeklinde yorumlanmaktadır. Araştırmada kullanılan görüşme formundaki soruların CVR değerleri Tablo'1de görüldüğü gibi +1 olarak hesaplanmıştır.

Tablo 1. Görüşme Sorularının CVR Değerleri

\begin{tabular}{ccccc}
\hline \multicolumn{5}{c}{ Uzman Görüşleri } \\
\hline Soru Numaras1 & Uygun değil & Kalabilir & Uygun & CVR Değeri \\
\hline 1 & 0 & 0 & 3 & 1 \\
2 & 0 & 0 & 3 & 1 \\
3 & 0 & 0 & 3 & 1 \\
4 & 0 & 0 & 3 & 1 \\
5 & 0 & 0 & 3 & 1 \\
6 & 0 & 0 & 3 & 1 \\
\hline
\end{tabular}

Soruların anlaşılırlığını tespit etmek amacıyla araştırmanın amaçlı örneklem grubunda yer almayan (ilkokullar bünyesindeki anasınıfında çalışmayan) ancak bağımsız anaokulunda görev yapan bir okul öncesi eğitim öğretmeni ile pilot görüşme yapılmış ve soruların açıklığı ve anlaşılırlığı teyit edilmiştir. Bu araştırmada görüşme sorularının okul öncesi eğitim alan uzmanlarına inceletilmesi ve katılımcılar dışındaki bir öğretmen ile pilot görüşme yapılması işlemleri gerçekleştirilerek iç geçerlilik(inandırıcılık) sağlanmaya çalışılmıştır. Görüşme formunda yer alan sorular şu şekildedir: 1) Yeni Eğitim Sistemi $(4+4+4)$ hakkındaki genel fikirleriniz nelerdir? 2)Yeni Eğitim Sistemi (4+4+4)'nin olumlu bulduğunuz yönleri nelerdir? 3) Yeni Eğitim Sistemi $(4+4+4)$ 'nin olumsuz (karşılaştığınız sorunlar) bulduğunuz yönleri nelerdir? 4)Yeni Eğitim Sistemi $(4+4+4)^{\prime}$ nin kesintili zorunlu eğitim sisteminin okul öncesi eğitimi ve anasınıflarını etkileyen yönleri nelerdir? 5) Yeni Eğitim Sisteminde (4+4+4) yaşadığınız sorunlara yönelik çözüm önerileriniz nelerdir? 6) Yeni Eğitim Sistemi (4+4+4) ile ilgili ne tür değişiklikler yapılmalıdır? Neden?

\section{Verilerin Analizi}

Araştırmanın verileri incelenirken, içerik analizi ve betimsel analiz yöntemleri kullanılmıştır. İçerik analizinde genel olarak yapılan işlem, birbirine benzeyen-yakın verilerin belirlenerek kavramlar ve temalar haline getirilmesi ve okuyucunun anlayacağı bir şekilde düzenleme ve yorumlamadır (Yıldırım ve Şimşek, 2013). İçerik analizinde öncelikle "verilerin analiz için hazırlanması ve düzenlenmesi" işlemi yapılmıştır. Bu aşamada araştırmanın amacına uygun olmayanlar (konuyla alakasız cevaplar, boş kâğıtlar vb.) ayıklanarak veriler analiz için hazır hale getirilmiş ve düzenlenmiştir. Daha sonra mevcut araştırmaya dair bilginin ve anlamının ne olduğuna dair derinlemesine düşünme imkânı veren "verilerin tamamını okuma veya inceleme" işlemi yapılmıştır. Bu aşamada araştırmacı(lar) tarafından bütün görüşme formları okunarak katılımcların görüşleri ile ilgili bir izlenim edinilmiştir. Üçüncü aşamada "verilerin kodlanması işlemi" yapılmıştır. Kodlama, araştırmada toplanan verilerin imgelere, cümlelere veya paragraflara ayrıştırılarak katılımcıların günlük hayatta kullandığ 1 dile uygun bir ifade ile kategorilerin isimlendirilmesini ifade etmektedir. Bu aşamada daha önceden okunmuş ve incelenmiş olan görüşme formlarındaki bilgilerin kodlanması ve uygun olan temalara yerleştirilmesi işlemi yapılmıştır. Daha sonra katılımcılardan elde edilen görüşler örnek ifadelerle desteklenerek veri analizinde son basamak olan "sonuçların ve bulguların nitel araştırmada yorumlanması" işlemi yapılmıştır (Creswell, 2013). Betimsel analizde ise; farklı veri toplama yöntemleri kullanılarak toplanmış olan verileri daha önceden oluşturulan temaların içine yerleştirilecek şekilde özetlenip yorumlanması işlemi yapılmaktadır. Betimsel analizde araştırmacının görüşme formlarından veya gözlem notlarından edindiği katılımcı görüşlerini etkili bir şekilde okuyucuya yansıtabilmek için doğrudan alıntıları sıklıkla kullandığı görülür. Buradaki en birincil amaç, elde edilen bulguları özet olarak düzenlenmiş ve yorumlanmış şekilde okuyucusuna sunulmasıdır (Yıldırım ve Şimşek, 2013). Bu araştırmada da katılımcı görüşlerinde doğrudan alıntılara sıklıkla yer verilerek betimsel analiz yönteminden faydalanılmıştır. McMillan (2000, aktaran Büyüköztürk ve diğerleri, 2009), nitel araştırmalarda araştırma verilerinin, verilerin analizinin ve sonuçlarının inanılırlık ve güvenilirlik ölçütlerini taşıması gerektiğini belirtmektedir. Nitel araştırmalarda araştırmada yapılan her bir işlemin ve izlenen yolun aşama aşama detaylı olarak tanımlanması, araştırmanın güvenirliğini artıran yöntemlerden biri olarak ifade edilmektedir (Büyüköztürk ve diğerleri, 
2009). Bu araştırmada da güvenirliğin sağlanması için araştırmada izlenen adımlar detaylı olarak tanımlanmıştır. Bir araştırmada "oluşturulan kodların farklı araştırmacılarca bağımsız olarak, ortaya çıkarılan sonuçların karşılaştırılması yoluyla çapraz kontrolün sağlanması diye tanımlanan kodlayıcılar arası uyum (çapraz kodlama), güvenirliği artırıcı diğer bir yol olarak ifade edilmektedir (Creswell, 2013). Mevcut araştırmada da güvenirlik ve iç geçerliğin sağlanması için görüşmelerden elde edilen cevaplar okul öncesi eğitimi alanında doktora yapmış iki farklı araştırmacı tarafından bağımsız olarak kodlanmıştır (Büyüköztürk ve diğerleri, 2009).

Tablo 2. Görüşme Verilerinin Kodlanmasına İlişkin Kodlama Uyum Oranları

\begin{tabular}{ccc}
\hline & Verilere İlişkin Kodlayıcılar Arası Uyum Oranları \\
\hline Soru Numarası & Kodlayıcılar Arası Uyum Oranı & $\% 94$ \\
1 & $\% 97$ & $\% 100$ \\
2 & $\% 100$ & $\% 92$ \\
3 & $\% 97$ \\
4 & & $\%$ \\
\hline
\end{tabular}

Kodlayıcılar arası uyum puanı birinci soru için \%94, ikinci soru için \%97, üçüncü soru için \%100, dördüncü soru için \%100, beşinci soru için \%92, altınca soru için \%97 ve araştırmanın geneli için \%96'dır. Miles ve Huberman, (1994, aktaran Creswell, 2013) iyi bir nitel güvenirliğin sağlanması için kodlayıcılar arasındaki uyumun .80 düzeyinde olması gerektiğini belirtmektedir. Nitel araştırmada "dış geçerlik" yerine kullanılan aktarılabilirlik için Erlandson ve diğerleri (1993, aktaran Yıldırım ve Şimşek, 2013). iki yöntem önermektedir. Bunlardan biri araştırmanın sonucunda ortaya çıkan kavram ve temalarla ilgili ham verilerin yeniden düzenlenerek doğrudan alıntılarla okuyucuya olduğu gibi sunulduğu "ayrıntılı betimleme" dir Araştırmada katılımcıların görüşlerinden alınan doğrudan alıntılara sık sık yer verilerek aktarılabilirlik sağlanmaya çalışılmıştır. Bu alıntılarda öğretmenler K1.(Ö), K2.(Ö), (K=Katılımc1) ve okul yöneticileri K20.(O.Y), K21.(O.Y) şeklinde kodlanmıştır. Aktarılabilirlik için önerilen diğer bir yöntem ise "amaçlı örnekleme" yapılmasıdır. Amaçlı örnekleme ise bilindik halleriyle karşımıza çıkan olay ve olguların değişkenlik gösteren özelliklerinin de ortaya konması amacını taşır. Araştırmada amaçlı örnekleme yapılarak aktarılabilirliğin artırılmasına çalışılmıştır (Yıldırım ve Şimşek, 2013).

\section{Bulgular}

Araştırmanın bu bölümünde; içerik analizi basamakları izlenerek hazırlanan bulgular tablolaştırılarak sunulmuştur.

Tablo 3. 4+4+4 Eğitim Sistemine Iliş̧kin Genel Görüşler Doğrultusunda Belirlenen Temalar, Kodlar, Frekans ve Yüzde Değerleri

\begin{tabular}{llcc}
\hline Temalar & Kodlar & $\mathrm{f}$ & $\%$ \\
\hline Eğitim sistemine ilişkin genel görüşler & Olumsuz & 12 & 28,57 \\
& Olumlu & 11 & 26,19 \\
& Illkokul süresi & 7 & 16,66 \\
& Kapsam & 6 & 14,29 \\
& Yorum yok & 3 & 7,14 \\
& Cevap vermeyen katılımc1 & 3 & 7,14 \\
& Toplam & 42 & 100 \\
\hline
\end{tabular}

\section{Eğitim Sistemine İlişkin Genel Görüşler}

Araştırmaya katılan anasınıfı öğretmenleri ve ilkokul yöneticilerinin $4+4+4$ eğitim sistemine ilişkin genel görüşleri incelendiğinde katılımciların çoğunluğunun (12/42) eğitim sistemi ile ilgili olumsuz görüşler beyan ettiği görülmüştür. K9.(Ö) bu konuda "pek verimli bulmuyorum" derken, K14.(Ö) "olumsuz düşünüyorum", K24.(O.Y) ise " yanlış bir sistem olarak görüyorum" demiştir. Katılımcıların bir diğer çoğunluğunun da (11/42) eğitim sistemini olumlu yönde değerlendirdiklerine dair ifadeler kullandıkları görülmüştür. K2.(Ö) bu konudaki düşüncelerini şöyle ifade etmiştir: "Olumlu katkı să̆laması amaçlanıp, geliştirilen bir model". 
K19.(O.Y)' da "genelde olumlu buluyorum" şeklinde görüş belirtmiştir. Katılımcılardan 7 kişi sisteme ilişkin genel görüşünde ilkokul süresinin 5 yıl olması gerektiği ile ilgili görüş beyan etmiştir. Bu konuda K27.(O.Y) “5. sımı öğrencilerinin ilkokul kısmına-sınıf öğretmenine tekrar verilmesi gerekiyor. Çünkü 5. simı öğrencileri davranışsal yönden sını öğretmeninin gösterdiği sevgiye ilgiye ihtiyaçları var. Aynı davranışı ortaokulda branş öğretmeni göstermediğinden öğrenci bocalıyor" demiştir. Katılımcılardan 6 kişi eğitim sistemine ilişkin genel görüşlerinde okul öncesi eğitimin de yeni eğitim sisteminin kapsamı içerisinde yer alması gerektiğinden bahsetmiştir. K7.(Ö) bu konudaki görüşünü şöyle ifade etmiştir: "Ortaokula geçen öğrenci küçük, bence 1+5+3+4 olmalıydı. Okul öncesi eğitim de girmeliydi". Yine K8.(Ö)'de benzer bir ifadeyle " $4+4+4$ değil de 1+5+3+3 olması çocukların gelişimleri açısından daha faydah olacaktır" demiştir. K42.(Ö) ise "Bence 5. sınıf çocuğunun ortaokula biraz erken başlaması onları olumsuz etkiliyor" demiştir. Araştırmada 3 katılımcı ise eğitim sistemine ilişkin olumlu veya olumsuz tam olarak bir açıklama yapamadıklarını belirtmişlerdir. Bu kişilerin görüşleri ise "yorum yok" şeklinde kodlanmıştır. Örneğin K36.(Ö) "Çok açık olarak şu veya bu, olumlu veya olumsuz bir fikir sunamıyorum" demiştir. 3 kişi bu soruya herhangi bir cevap vermemiştir.

Tablo 4. 4+4+4 Eğitim Sisteminin Olumlu Yönleri Doğrultusunda Belirlenen Temalar, Kodlar, Frekans ve Yüzde Değerleri

\begin{tabular}{|c|c|c|c|}
\hline Temalar & Kodlar & f & $\%$ \\
\hline \multirow[t]{10}{*}{ Ĕ̆itim sisteminin olumlu yönleri } & Olumlu yanı yok & 12 & 28,57 \\
\hline & Eğitim süreci & 8 & 19,05 \\
\hline & Okul yaşı & 6 & 14,28 \\
\hline & Cevap vermeyen katılımcı & 4 & 9,52 \\
\hline & Okul süresi & 3 & 7,14 \\
\hline & Fiziki ortam & 3 & 7,14 \\
\hline & Süreklilik & 3 & 7,14 \\
\hline & Zorunlu olması & 2 & 4,76 \\
\hline & K1z çocukları & 1 & 2,38 \\
\hline & Toplam & 42 & 100 \\
\hline
\end{tabular}

\section{Eğitim Sisteminin Olumlu Yönleri}

Katılımcıların 4+4+4 eğitim sisteminin olumlu yönlerine ilişkin görüşleri incelendiğinde, 12 kişi eğitim sisteminin olumlu bulduğu bir yönü olmadığını belirtmiştir. Örneğin, K2.(Ö) "Olumlı yanı yok" demiştir. K14.(Ö) ise "olumsuz düşünüyorum" şeklinde görüş belirtmiştir. Katılımcılardan 8 kişi ise yeni eğitim sistemini, eğitim süreci açısından olumlu bulmuşlardır. K19.(O.Y) bu konuda "Bütün öğrenciler belli eğitim sürecinden geçtikleri için eğitim ve kültür seviyesi artmaktadır" derken; K42.(Ö) "Ders konularının daha oranlı dağıldığıı düşünüyorum" diyerek ifade etmişlerdir. Katılımcılardan 6 kişi okula başlama yaşının eğitim sisteminin olumlu yanlarından biri olduğunu belirtmiştir. K11.(Ö) "Çocukların daha erken orta öğretime başlaması" derken, K38.(Ö) "Çocuklarm erken dönemde yeteneklerine göre yönlendirildiğini düşünüyorum” demiştir. 4 kişi bu soruya herhangi bir cevap vermemiştir. Katılımcılardan 3 kişinin okul süresini yeni eğitim sisteminin olumlu yönlerinden biri olarak ifade ettiği görülmektedir. K3.(Ö) bu konuda "ilkokulun 4 yıl olması" şeklinde görüş belirtmiştir. K20.(O.Y) ise "lisenin 4 yıl olması" olarak fikir belirtmiştir. Katılımcılardan 3'ünün ise eğitim sisteminin olumlu bulduğu yönlerinden biri olarak "fiziksel ortam" konusundan bahsettiği görülmüştür. Bu konuda K8.(Ö) "6 yaşındaki bir çocukla, 14 yaşındaki bir gencin farklı ortamda eğitim alması" diyerek ilkokul ve ortaokul binalarının ayrılmasına değinmiştir. K40.(O.Y) ise bunu "Okul bahçelerinin ayrılmış olması mükemmel oldu" şeklinde ifade etmiştir. Katılımcılardan 3 kişinin ise yeni eğitim sistemini "süreklilik" yönüyle olumlu bulduğu görülmektedir. Katılımc1lar K26.(O.Y) ve K35.(O.Y) bunu "Süresi" ve "Eğitim sürekli hale gelmiştir" diyerek belirtmişlerdir. Katılımcılardan 2 kişi zorunlu olmasının bu eğitim sürecinin olumlu yönlerinden olduğunu belirtmiştir. Sırasıyla K9.(Ö) ve K7.(Ö) bunu "Zorunlu olması iyi oldu" ve "zorunlu olması" diyerek ifade etmişlerdir. Katılımcılardan 1 kişi (K.30-O.Y) yeni eğitim sisteminin olumlu yönünü "kız çocukları" açısından değerlendirmiş ve "özellikle bazı bölgelerde bazı aileler kız çocuklarını ilkokuldan sonra okutmuyorlardı. 4+4+4 eğitim sistemi sayesinde kız çocukları okuma imkanı bulmuştur" diyerek ifade etmiştir.

Tablo 5. 4+4+4 Ĕ̆itim Sisteminin Olumsuz Yönleri Doğrultusunda Belirlenen Temalar, Kodlar, Frekans ve Yüzde Değerleri 
Anasınıfı Öğretmenleri ve İlkokul Yöneticilerinin ...

\begin{tabular}{llll}
\hline Temalar & Kodlar & $\mathrm{f}$ & $\%$ \\
\hline Eğitim sisteminin olumsuz yönleri & Erken başlama & 19 & 45,24 \\
& Zorla eğitim & 5 & 11,90 \\
& Olumsuz yanı yok & 4 & 9,52 \\
& Cevap vermeyen katılımc1 & 4 & 9,52 \\
& Altyapı eksikliği & 3 & 7,14 \\
& Eğitimin süresi & 3 & 7,14 \\
& Mesleki yönelim & 3 & 7,14 \\
& Karma yaş grubu & 1 & 2,38 \\
& Toplam & 42 & 100 \\
\hline
\end{tabular}

\section{Eğitim Sisteminin Olumsuz Yönleri}

Eğitim sisteminin olumsuz yönleri ile ilgili bulgular incelendiğinde; katılımcıların büyük çoğunluğunun (19/42) okullara erken başlanmasını eğitim sisteminin olumsuz yönlerinden biri olarak ifade ettiği görülmüştür. K22.(O.Y) "Zihinsel olarak gelişimini tamamlamayan çocukların okula başlaması akademik beceriye olumsuz olarak yansıdı" ve K38.(Ö) "Çocukların 6 yaşında 1. sınıfa alınmasını doğru bulmuyorum" diyerek bu konudaki görüşlerini ifade etmişlerdir. Katılımcılardan 5 kişi 12 yıllık zorunlu eğitimin okula devam etmek istemeyen öğrenciler açısından zorunluluk oluşturmasını, yeni eğitim sisteminin olumsuz bulduğu yönlerden biri olarak göstermiştir. K27.(O.Y) “Öğrenciyi zorunlu olarak eğitim sisteminin içinde tutmaya çalışıyoruz. Akademik olarak başarll olamayacak öğrenci sistem içerisinde diğer öğrencilere kötü örnek oluyor" derken, K30.(O.Y) "İlkokuldan sonra okuyamayacak durumdaki kişiler zorla okulda tutulmaya çalışılıyor. Sanayide ve esnaf yanında çırak bulunamıyor. Lise mezunu ve üniversite mezunu işsizler çoğalıyor" demiştir. Katılımcılardan 4 kişi olumsuz yanı yok şeklinde görüş belirtmiştir. K5.(Ö) "Olumsuzluk yok" derken, K10.(Ö) Sadece "Yok" demiştir. 4 kişi bu soruya herhangi bir cevap vermemiştir. Araştırmaya katılanlardan 3 kişinin altyapı eksikliklerinden bahsettiği görülmüştür. K9.(Ö) bu konuda "altyapr yetersizliği" diyerek, K39.(O.Y) ise "okul binalarmın tamamının sistemin gerektirdiği şekilde ayrılmamış olması" şeklinde görüşlerini ifade etmişlerdir. Katılımcılardan 3 kişi eğitimin süresini olumsuz bir durum olarak değerlendirmiştir. K19.(O.Y) "Süreç uzun oldŭ̆u için devamsızlık ve sistemden ayrılmalar fazla oluyor" derken, K37.(O.Y) "Illkokulun 5 yıl olması gerekir" demiştir. Son olarak 3 kişi de yeni eğitim sistemini mesleki yönelim açısından olumsuz bulmuştur. K6.(Ö) "Tam ergenlik döneminde ortaokula geçiyorlar. Yeteneklerine göre yönlendirilmiyor. Sinav sistemi yanlış, sinav olmadan yeteneklerine göre meslek seçimi olmalı" derken, K20.(O.Y) "íkinci dörtten sonra meslek lisesi ve çıraklı eğitimine yöneltmede problem yaşanması" diyerek görüşlerini ifade etmiştir. Katılımcılardan 1 kişi yeni eğitim sistemiyle birlikte karma yaş grubu oluştuğunu ve bu durumun olumsuzluğundan bahsetmiştir. K12.(Ö) “Okul öncesi eğitimin erken yaşta olması, karma yaş grubunun olması, çocukların annelerinden ayrılmak istememesi, bağımsız hareket etme istekleri, fiziksel koşulların uygun olmaması gibi sonuçlar doğurmuştur" şeklinde bu durumu ifade etmiştir.

Tablo 6. 4+4+4 Eğitim Sistemi ile İlgili Sorunlara Sunulan Çözüm Önerileri Doğrultusunda Belirlenen Temalar, Kodlar, Frekans ve Yüzde Değerleri

\begin{tabular}{llcc}
\hline Temalar & Kodlar & f & $\%$ \\
\hline Sorunlara ilişkin çözüm önerileri & Öneri yok & 10 & 23,81 \\
& İlkokul 5 yll olmalı & 7 & 16,66 \\
& Zorunlu okul öncesi eğitim & 5 & 11,90 \\
& Okula başlama yaşında esneklik & 4 & 9,52 \\
& Cevap vermeyen katılımcı & 4 & 9,52 \\
& Mesleklere yönelim & 3 & 7,14 \\
& Erken başlamamalı & 3 & 7,14 \\
& Lise serbest olmalı & 2 & 4,76 \\
& 8 yıllık eğitim & 2 & 4,76 \\
& Gruplama & 2 & 4,76 \\
\hline
\end{tabular}

\section{Sorunlara İlişkin Çözüm Önerileri}

Araştırmaya katılan öğretmenler ve okul yöneticilerinin 4+4+4 eğitim sistemiyle ilgili yaşadıkları sorunlara ilişkin çözüm önerileri incelendiğinde; katılımcılardan 10 kişinin herhangi bir öneride bulunmadığ 1 veya soru ile ilgisiz yanıtlar verdiği görülmektedir. K36.(Ö) "Önerim yok" demiştir. 7 kişi "ilkokul 5 yıl olmalı" derken K2.(Ö) bunu "5+3+4 tekrar dönüşebilir" şeklinde dile getirmiştir. K23.(O.Y) ise "Illkokul 5 yıl olmall, 
ortaokul ve lise zorunlu olmamalı" demiştir. Katılımcılardan 5 kişi de "zorunlu okul öncesi eğitim" konusunu çözüm önerisi olarak sunmuştur. K38.(Ö) "Okul öncesi eğitim zorunlu olmalı" ve K4.(Ö) "illkokul 6 yıl olmall, okul öncesi de dahil, sonra 3 yıl orta okul 3 yıl lise olmalı diye düşünüyorum" diyerek görüşlerini belirtmişlerdir. Katılımcılardan 4 kişi “okula başlama yaşında esneklik" sağlanması gerektiğini vurgulamıştır. K27.(O.Y) "1. Sınıfa başlayacak öğrenci yaş sorunu. Yönetmeliğimiz 30 Eylül tarihi itibari ile 72 ayını dolduran öğrenciyi otomatikman 1. Sınıfa aktarıyor. Ama 1 Ekimde doğan öğrenciyi velinin isteğine bırakıyor. Önerimiz, daha önceki yönetmeliğimizde olduğu gibi 30 Kasıma kadar öğrenci gözlemlenip, 1. Sınıfı yapıp yapamayacă̆ı kanaati oluşan öğrenci hakkında sınıf öğretmeni, veli, rehber öğretmen ve okul idaresi tarafından oluşturulan komisyon tarafindan anasımıfina çekme yetkisi verilmesi" derken, K8.(Ö) "Illkokula başlama yaşı serbest olmalıdır, veli kendi belirlemelidir" demiştir. 4 kişi bu soruya herhangi bir cevap vermemiştir. Katılımcıların 3'ü "mesleki yönelim" konusuna dikkat çekmiştir. Bu konuda K3.(Ö) "mesleki gelişim açısından liseler zorunlu olmasın" demişken, K13.(Ö) "Okul öncesi zorunlu olmall, eğitim 5+3+3 olması gerekir. Ortaokul zorunlu olmall, lise değil. Okuma kapasitesi olmayan çocuklar meslek gruplarına yönlendirilmeli. Liseden sonra meslek eğilimi olmuyor" demiştir. Katılımcılardan 3 kişi "erken başlamamalı" diyerek görüş belirtmişlerdir. K22.(O.Y) "En az 72 ayını dolduran çocuğun ilkokula başlaması gerekmekte" demiştir. Katılımciların 2'si "lise serbest olmalı" önerisini sunmuşlardır. K24.(O.Y) "Illkokulun 5 yıl olarak düzenlenmesi gerektiğini, özellikle lisenin zorunlu olmaktan çıkarılması gerektiğini düşünüyorum" demiştir. K32.(O.Y) ise bunu "lise dönemi zorunlu olmamalı" diyerek ifade etmiştir. Son olarak 2 katılımcı ise "8 yıllık eğitim" önerisini sunmuştur. K33.(O.Y) "Kesintisiz 8 yillık eğitime geri dönülmeli" ve K15.(Ö) "5+3+3 geri dönülmeli" demiştir. Katılımcılardan 2 kişi çocukların "gruplanması" gerektiğinden bahsetmiştir. K12.(Ö) "Yaş gruplarının çocukların gelişimsel özelliklerine göre olması, ilkokula başlama yaşının en az 66 ay olarak düzenlenmesi ve sistem için fiziksel açıdan kaliteli eğitim ortamlarının oluşturulması olabilir" demiştir.

Tablo 7. 4+4+4 Eğitim Sisteminin Okul Öncesi Ĕ̆itimi Etkileyen Yönleri Doğrultusunda Belirlenen Temalar, Kodlar, Frekans ve Yüzde Değerleri

\begin{tabular}{llcc}
\hline Temalar & Kodlar & $\mathrm{f}$ & $\%$ \\
\hline Eğitim sisteminin okul öncesi eğitime etkileri & Etkilemiyor & 14 & 33,33 \\
& Zorunlu okul öncesi eğitim & 7 & 16,66 \\
& Ilkokula erken başlama & 6 & 14,28 \\
& Fiziksel mekân & 5 & 11,90 \\
& Cevap vermeyen katılımc1 & 5 & 11,90 \\
& Karma yaş grubu & 3 & 7,14 \\
& Okula göndermeme & 2 & 4,76 \\
& Toplam & 42 & 100 \\
\hline
\end{tabular}

\section{Eğitim Sisteminin Okul Öncesi Eğitime Etkileri}

Katılımcıların 4+4+4 eğitim sisteminin okul öncesi eğitimi etkileyen yönlerinin neler olduğu sorusu ile ilgili görüşlerine bakıldığında; 14 kişinin "etkilemiyor" dediği görülmektedir. K2.(Ö) bu konuda "sisteme okul öncesi eğitimini tamamladıktan sonra girdikleri için bence etkilemiyor" diye, K34.(O.Y) "Okul öncesini etkileyen bir yönü yok" şeklinde görüş belirtmişlerdir. Katılımcılardan 7 kişi ise bu konuda "zorunlu okul öncesi eğitime" vurgu yapmışlardır. K12.(Ö) "Okul öncesi eğitim öğrenmenin temelidir ve zorunlu olmalıdır. 4+4+4 eğitim sisteminin içerisine dahil edilmelidir" diyerek, K36.(Ö) ise "Anasınıfı zorunlu olmadıkça eğitim tam anlamılla eğitim olmuyor" şeklinde görüş belirtmişlerdir. Araştırmaya katılanlardan 6 kişi ise "ilkokula erken başlama" konusunda okul öncesi eğitimin yeni eğitim sisteminden etkilendiğini söylemişlerdir. Bu konuda K13.(Ö) "Okul öncesini etkilediğini düşünmüyorum. Sadece çok erken yaşta ilkokula başladıklarının çocukları çok kötü etkilediğini biliyorum ve düşünüyorum" derken, K38.(Ö) "66 ayını doldurunca çocukların 1. sımıfa başlamaların doğru bulmuyorum. Okul öncesine gitmeli" demiştir. 5 kişi "fiziksel mekân" konusunda yeni eğitim sisteminin okul öncesi eğitimi etkilediğini belirtmişlerdir. Bu konuda K25.(O.Y) "Ortaokullarla anasınıfları aynı mekânda sağlıklı olmuyordu, şimdi daha iyi" derken, K39.(O.Y) "Anasınıflar kesinlikle ilkokullar bünyesinde olmalıdır. Diğer kademelerde bulunmasının öğrenciler için uygun olmadığın düşünüyorum" demiştir. 5 kişi bu soruya herhangi bir cevap vermemiştir. Katılımcılardan 3 kişi "karma yaş grubu” koduyla okul öncesi eğitimin $4+4+4$ eğitim sisteminden etkilendiğini belirtmişlerdir. K4.(Ö) "Çok küçük yaşlarda anasımıfina başlamaları ve karma yaş grubunun anasınıfına kaydolması" şeklinde belirtirken, K15.(Ö) "Sinıfta küçük ve karma yaş grubu oluşuyor, bu yüzden sıkıntı" diyerek bu konudaki görüşünü belirtmiştir. Katılımcıların 2'si ise eğitim sürecinin uzunluğu dolayısıyla "okula göndermeme" konusuna değinmiştir. Konuyla ilgili olarak K37.(O.Y) "Okul süresinin uzun olması anasınıfına 
Anasınıfı Öğretmenleri ve İlkokul Yöneticilerinin ...

gönderme oranın düşürdü" şeklinde görüş belirtirken K19.(O.Y) “Veliler 12 yıl zorunlu eğitim uzun olduğu için, küçük yaşta çocukların sorumluluk almasını istememektedir" demiştir.

Tablo 8. 4+4+4 Ĕ̆itim Sisteminde Yapılması Gereken Değişiklikler Doğrultusunda Belirlenen Temalar, Kodlar, Frekans ve Yüzde Değerleri

\begin{tabular}{|c|c|c|c|}
\hline Temalar & Kodlar & $\mathrm{f}$ & $\%$ \\
\hline \multirow[t]{10}{*}{ Okul öncesi eğitime yönelik düzenlemeler } & Zorunlu okul öncesi eğitim & 20 & 47,62 \\
\hline & Destek & 4 & 9,52 \\
\hline & Müfredat & 4 & 9,52 \\
\hline & Cevap vermeyen katılımcı & 4 & 9,52 \\
\hline & Kalite & 3 & 7,14 \\
\hline & Yaş grupları & 2 & 4,76 \\
\hline & Yaş değişikliği & 2 & 4,76 \\
\hline & Ulaşılabilirlik & 2 & 4,76 \\
\hline & Öneri yok & 1 & 2,38 \\
\hline & Toplam & 42 & 100 \\
\hline
\end{tabular}

\section{Okul öncesi eğitime yönelik düzenlemeler}

Araştırmada 4+4+4 eğitim sistemi ile ilgili bir değişiklik/düzenleme yapılacak olursa okul öncesi eğitim ve anasınıfları için ilişkin ne tür değişiklikler yapılmasını istersiniz? sorusuna katılımcıların verdiği cevaplar incelendiğinde; katılımcıların yaklaşık olarak yarısı (20/42) okul öncesi eğitimin zorunlu olması gerektiğini ifade etmişlerdir. K7.(Ö) ve K36(Ö) sırasıyla "Zorunlu olmalı ve sınıflardaki sayının 20'den fazla olmaması gerekir" ve "0-6 yaş çok önemli bir dönem, okul öncesi eğitimin zorunlu olmasını istiyorum" demiştir. 4 kişi ise "destek" sunulması gerektiğinden bahsetmiştir. K6.(Ö) "Zorunlu olması gerekir. Gerekli ödeneğin verilmesi gerekir. Velilerin ve idarecilerin gerekli desteği vermesi gerekir. Okul öncesi bakıcı değil, eğitim ve öğretimin yapıldı̆̆ı bir kurum olduğu bilincine varılması gerekir" şeklinde ifade ederken, K5.(Ö) "Ĕ̆itimin mecburi olması, küçük yaş grubunun alınmaması, devletin ortak plan ve yeterli kaynak vermesi, sorunlar görmesi için idareci vermesi gerekir" demiştir. Katılımcılarda 4 kişi "müfredat" konusunda değişiklik talep ettiği görülmektedir. K40.(O.Y) "Müfredat programı sadeleştirilmesi... Öğretmenler etkinlikler konusunda seminerlere alınmalı. Satranç ve zeka oyunları ağırlıklı olmalı. okuma yazma boyama daha geri planda kalmalı" şeklinde görüş belirtirken, K18.(Ö) "Müfredat yenilenmeli, güncel etkinlikler olmalı eski konu planlama sistemi çok daha kaliteliydi bence. O sisteme geri dönülmeli. Aşamalı veya seçmeli müfredat olmall, örneğin köyler için ayrı, küçük şehirler için ayrı büyük şehirler için ayrı. Öğretmenler çalıştıkları yerin özel durumuna göre müfredatla çalışmalı. İstanbul'da dil gelişimi çok önemli değilken, doğu illerimizde dil gelişimine daha çok ihtiyaç duyulmakta. Doğu illerindeki çocukların problem çözme yetenekleri gelişmişken, batı illerindeki çocuklarda problem çözme yeteneği neredeyse hiç yok. Böylelikle bu denge müfredatla korunabilir ve eşitlik sağlanır" demiştir. 4 kişi bu soruya herhangi bir cevap vermemiştir. Katılımcılardan 3 kişi "kalite" konusunda değişiklik önerisinde bulunmuştur. Bu konuda K1.(Ö) "illkokuldan bağımsız olması, yöneticilerin uzman kişilerden olması" demiştir. 2 katılımcının ise "yaş grupları" ile ilgili değişiklik yapılması gerektiğine dikkat çektiği görülmektedir. K12.(Ö) "Sınıfların yaş gruplarına göre düzenlenmesini ve fiziksel açıdan çocuğa uygun eğitim ortamı yaratılmasını isterim" derken, K15.(Ö) "Anasımılarında da anaokullarındaki gibi yaş grupları ayr olmalı ve anaokullarındaki imkanlar anasımfflarında da olmalı" demiştir. 2 katılımonın "yaş değişikliğinden" bahsettiği görülmüştür. K9.(Ö) "Okula başlama yaşında değişiklik yapılması gerekir" derken, K4.(Ö) "Anasınıfı yaşı 66-72 ay olmalı. Çünkü ilkokula hazırlıkta hazırbulunuşluk çok önemli" demiştir. Son olarak 2 katılımcı "ulaşılabilirlik" ile ilgili düzenleme yapılması gerektiğini belirtmiştir. K42.(Ö) "Atama kontenjanları artırılmalı" diyerek daha çok okul öncesi eğitim öğretmeni ve böylece daha çok okul öncesi eğitim kurumunun açılması fikrini öne sürdüğü, K30.(O.Y) "anasinıflar da zorunlu olmal, anaokulu sayısı artırlmalı, velilerden aidat alınmamalı" şeklinde görüş belirttiği görülmektedir. Katılımclardan K29.(Ö) herhangi öneride bulunmamıştır ve bunu "önerim yok" diyerek belirtmiştir.

\section{Tartışma}

Araştırmada; 4+4+4 eğitim sisteminin okul öncesi eğitimi etkileyen yönlerinin neler olduğu, olumlu ya da olumsuz hangi yönde etkilediği, var olduğu düşünülen sorunların tespit edilmesi ile birlikte bu sorunların 
giderilmesi için ne gibi çözümler üretilebileceği ve ne gibi düzenlemeler yapılması gerektiği belirlenmeye çalışılmıştır. Anasınıfı öğretmenleri ve ilkokul yöneticilerinin yeni eğitim sistemine ilişkin genel fikirlerinin olumlu buluyorum/ olumsuz buluyorum şeklinde, herhangi bir açıklayıcı ifadeye yer verilmeksizin kısa cevaplar şeklinde olduğu ve bazı katılımcıların ise bu konuya ilişkin bir fikir belirtmedikleri görülmektedir. Bu durum katılımcıların yarısını anasınıfı öğretmenlerinin oluşturması ile açıklanabilir. Çünkü anasınıfları, çoğunlukla ilkokullar veya ortaokullar bünyesinde bulunmalarına rağmen okulun işleyişinden bağımsız bir varlık sürdüren, öğretmenler ise okulla ilgili süreçlere dahil olmayan/dahil edilmeyen bir konumdadırlar. İlkokullarla veya ortaokullarla ayn fiziksel ortamda bulunup, aynı yönetici tarafından idare edilen anasınıflarının, 4+4+4 zorunlu eğitim sisteminin dışında tutulmasının bir sonucu olarak, anasınıfı öğretmenleri eğitim sistemi ile ilgili açıklayıcı görüşler belirtememektedir. Bu nedenle öğretmenlerin eğitim sistemine ilişkin olumlu veya olumsuz derinlemesine bir yorumsal fikre sahip olamadıkları düşünülmektedir. Diğer taraftan, okul öncesi eğitimin de $4+4+4$ eğitim sisteminin dışında bırakılmaması zorunlu eğitim sistemine dahil edilmesi gerektiği araştırmada elde edilen en önemli bulgularından biridir. Okul öncesi eğitim, erken çocukluk dönemini kapsayan bir dönem olması sebebiyle aile tarafından bu dönemde çocuğa zengin uyarıcıların olduğu bir ortam sunulup sunulamaması, gelişimsel açıdan büyük bir etkiye sahiptir (Başaran, Dursun, Gür Dortok ve Yılmaz, 2021). Çocuğun sosyal, duygusal, dil, motor ve bilişsel gelişim alanlarında sağlam bir temel oluşturması bu dönemdeki beyin gelişimi ile yakından ilişkilidir (Başaran ve diğerleri, 2021). Konuya bu yönüyle bakan anasınıfı öğretmenleri, okul öncesi eğitimin de zorunlu eğitim sisteminin kapsamına alınması gerektiğini belirtmişlerdir. Literatürdeki bilgiler de bu yöndedir. AÇEV ve ERG (2013)'nin birlikte hazırladığ 1 "Erken Çocukluk Eğitimi ve 4+4+4 Düzenlemesi" başlıklı raporda okul öncesi eğitimin, eğitimin ilk kademesi olması sebebiyle gömleğin ilk düğmesi gibi olduğu, doğru iliklenmediği takdirde diğer düğmelerde de düzensizlikler olacağı belirtilerek okul öncesi eğitimin önemine ve gerekliliğine dikkat çekilmiştir. Araştırma sonucunda okul süresi ile ilgili, özellikle ilkokulun 5 yıl olmasının gerekliliği görülmektedir. Çocukların ortaokula geçişiyle beraber derslerin çok daha fazla branşa ayrılması ve her ders için farklı bir öğretmenle karşılaşmak pedagojik açıdan sorunlar oluşturabilir. İlkokula başlama yaşının erkene çekilmesine ek olarak, daha sıcak bir bağ kurulan ilkokul öğretmeninden de bir yıl erken ayrılmak bu yaştaki çocuklar açısından ortaokula uyum ve sonraki eğitim yaşantısında süreklilik sağlayamama sorunları oluşturabilir. Özdemir ve Battal (2019)'ın yaptıkları araştırmada, yeni sistemle birlikte ilkokula daha erken başlamak zorunda kalan çocukların; gelişimsel özellikleri ve kendisinden beklenen görevleri yerine getirmedeki yetersizlikleri nedeniyle okula hazırbulunuşluklarının düşük olduğu, uyum sorunları yaşadıkları ve akademik başarılarının düşük olduğu bulunmuştur. Bu sonuç mevcut araştırma sonuçlarında ortaya konan ilkokul süresinin 5 yıl olması gerekliliğini doğrular niteliktedir. Yine ilkokulun 4 yıla indirilmesi ilkokul 5 . sınıf öğretmenlerinin norm fazlası durumuna düşmesi ve bu öğretmenlerin bakanlık tarafından farklı branşlara geçmesine izin verilmesi nedeniyle de farklı sorunlar ortaya çıkarmıştır (Eğitim-Bir-Sen, 2013; Doğan, Demir ve Pınar, 2014). Aytaçlı ve Gündoğdu, (2018) tarafından yapılan araştırmada ise 4+4+4 eğitim sistemi ile henüz soyut işlemler dönemine geçmemiş çocukların (5. sınıfların) dersine giren matematik öğretmenlerinin, eğitim sistemine geçiş öncesinde hizmet içi eğitim verilmediği için sorunlar yaşadıklarını ortaya çıkarmıştır.

Araştırmada aralarında büyük yaş farkı bulunan (5yaş-14yaş gibi), aynı bahçeyi ve okul binasını kullanmak zorunda olan çocukların yeni eğitim sisteminin kademelendirilmesi ile bundan kurtulmuş olması eğitim sisteminin olumlu değerlendirilen yönlerindendir. Külekçi (2013)'nin öğretmen görüşlerine yer verdiği araştırmasında eğitim kademelerinin ilkokul ortaokul şeklinde ayrılması ile birlikte okul içerisinde küçük çocukların her yönden daha rahat hareket edebildiği dile getirilmektedir. Araştırma sonuçlarının ortaya koyduğu bir diğer nokta olan eğitim sisteminin 12 ylllık bir zorunlu eğitim süreci şeklinde planlanması, toplumsal eğitim seviyesinin yükseltilmesi bakımından önemli bir fırsat olarak değerlendirilmektedir. Ancak burada dikkat edilmesi gereken nokta, ilkokula başlayacak tüm çocukların okul öncesi eğitim alarak ilkokula hazırbulunuşluklarının en üst düzeyde olması gerekliliğidir. Okul öncesi eğitimin yaygınlaştırılması çalışmalarının 65. Hükümet programında vurgulanmış olmasına, Kalkınma Bakanlığı'nın 2017-2019 Orta Vadeli Program'ında okul öncesi eğitimin 2019 yılına kadar kademeli olarak zorunlu eğitime dahil edilmesi hedefi yer almasına ve Milli Eğitim Bakanlığı tarafından 2017-2018 eğitim öğretim yılı itibariyle pilot 
uygulamaların yapılması için bazı illere yazı gönderildiği bilgisinin kamuoyuna sunulmuş olmasına rağmen, henüz okul öncesi eğitimin zorunlu eğitim sürecine dahil edilmesi ile ilgili çalışmaların yapılıp yapılmayacağı belirsizliğini korumaktadır (Türkiye Eğitim Derneği (TEDMEM), 2017). Bu durum erken yaşta ilkokula başlayan çocuklar açısından daha önce de ifade edildiği gibi yetersiz düzeyde okula hazırbulunuşluk, uyum sorunları ve bunların sonucunda akademik başarısızlık olarak kendini gösterecektir. Epçaçan (2014)'ın yaptığı araştırmada da eğitim kademelerinin birbirinden ayrılması, mevcut araştırma bulguları ile tutarlı olarak sistemin güçlü yanlarından biri olarak ortaya konmuştur. Yine 12 yıllık zorunlu eğitim sistemi, eğitim hayatından çok erken koparılan kız çocuklarının eğitime devam edebilecek olmaları açısından umut verici bir gelişme olarak değerlendirilebilir. Ancak bu durum, teoride kalmamalıdır. Eğitim hayatından erken koparılan kız çocuklarının velileri ile ilgili gerekirse caydırıcı yaptırımlar uygulanmalıdır. Hacettepe Üniversitesi Senatosu (2012)'nun 4+4+4 eğitim sistemi ile ilgili yayınladığ 1 görüşünde “okullaşma oranı \% 85'den \%98'e, kızların okullaşma oranı ise daha yüksek bir artışla \% 79'dan \%98'e çımııs ve kızların okula erişimi erkeklerle eşit düzeye gelmiştir" denilmektedir. Bu verilere bakılarak, kızların okullaşma oranında zorunlu eğitim sistemi ile olumlu bir gelişme yaşandığı ifade edilebilir. Diğer taraftan Boğaziçi Üniversitesi Eğitim Fakültesi (2012), 4+4+4 eğitim sistemi ile ilgili kamuoyuna ilettiği görüşünde, “Okulöncesi eğitimin tüm çă̆ nüfusuna zorunlu olarak iletilmemesi, okullaşma süreçlerine hazırlı açısından alt sosyo-ekonomik düzeyden gelen çocuklar aleyhine, onarılması güç eşitsizlikler oluşturacaktır "demiştir. Ankara Üniversitesi Eğitim Fakültesi (2012) ise "kanun teklifi ile farklı toplumsal gruplar ve tabakalardan çocukların eğitim hakkı engellenmekte, eğitimde eşitlik ilkesi zedelenmektedir. Kanun teklifi, 8 yıllık temel eğitimi fiilen 4 yıla indirerek kız çocuklarının, yoksul çocukların, köy çocuklarının ve engelli çocukların üst öğrenime devam etme olanaklarını ortadan kaldırmaktadır. Tasarı, çocuk işçiliğini, toplumsal cinsiyet eşitsizliği ve ayırımcılı̆̆l, sinıfsal ayrışmayı, köy-kent kutuplaşmasını teşvik etmekte, çocukların toplumsallaşarak bütünsel ve çok yönlü gelişiminin önünü kapatmaktadır" diyerek uygulamayı eleştirmektedir.

Araştırma sonuçlarına göre; altyapı eksiklikleri giderilmeden ve gerekli ön hazırlıklar yapılmadan eğitim sisteminde değişikliğe gidilmesi, eğitim sisteminin bütününe ilişkin olumsuz bir algı oluşturmaktadır. Bu sonuç, Kara (2020)'nın eğitim paydaşları (öğretmen, öğrenci, veli, okul yöneticisi, sivil toplum kuruluşu temsilcisi ve öğretim elemanı) ile yaptı̆̆ı araştırmada Türk Eğitim Sistemi'nin 42 temel sorunu içerisinde en sık tekrar edilen sorunlardan biri olarak 4+4+4 eğitim sisteminin ifade edilmesi ile de tutarlılık göstermektedir. İlgili araştırmada yeni eğitim sistemi bütünüyle bir sorun olarak ifade edilmiştir. Buna ek olarak 12 yıllık zorunlu eğitim sürecinin okula devam etmek istemeyen öğrencileri zorla eğitim sürecinin içinde tutmaya çalıştığı, bunun sonucunda bu öğrencilerin okula devam etme ve davranışsal uyum sorunları nedeniyle diğer öğrenciler açısından kötü rol model anlamına geldiği, zorunlu eğitim nedeniyle sanayide ve esnaf yanında çırak bulunamadığı, lise ve üniversite mezunu işsizlerin çoğaldığı ortak görüşünü ortaya çıkarmıştır. Bu bulguya ilişkin olarak, okulların rehberlik servisleri aracılı̆̆ıyla okula devam etmek istemeyen öğrenciler ve aileleri ile görüşülerek öğrencilerin eğitim hayatına devamının sağlanması ve uyum sorunlarının çözümü konusunda işbirliği yapılmalıdır. Bu öğrencilerin okula uyum ve eğitim sürecine devam etmesi konusunda yapılanların sonuç vermemesi durumunda, çıraklık ve kalfalık eğitimi ile zorunlu eğitim sürecinin tamamlanmasına imkan tanınması bir çözüm olarak düşünülebilir. Mevcut araştırmanın ortaya koyduğu bulgulardan bir diğeri de çocukların ilkokula daha erken başlamasıyla okul öncesi eğitime-anasınıflarına gelen yaş grubunun küçülmesidir. Bu durum Can ve Kılıç (2019)'ın yaptığı araştırmada da ortaya konmuştur. Okula başlama yaşının küçülmesiyle birlikte okul öncesi eğitim özbakım becerilerinin kazandırılmasına yönelik bir eğitime dönüşmüştür (Can ve Kılıç, 2019). Bununla birlikte çocuğunu ilkokula erken başlatmak istemeyen bazı ebeveynler de sağlık raporu alarak ilkokul eğitimini 1 yıl erteleyerek çocuğunu tekrar anasınıfına göndermektedir. Bu durumda anasınıflarında 4-5-6 yaş gibi gelişimsel açıdan tamamen birbirinden farklı olan karma yaş grubu bir sınıf ortaya çlkmaktadır. Bu durumda büyük çocuklara uygun etkinlikler planlandığında küçük çocukların zorlanması, daha basit etkinlikler planlandığında ise büyük çocukların ilgisini çekmeyeceği ve her iki grup için de okul öncesi eğitimin çekiciliğini kaybedeceği açıktır. Sonuç olarak ilkokullar bünyesindeki anasınıflarının fiziki alan, maddi destek ve personel imkânlarının ne kadar sınırlı olduğu düşünüldüğünde oluşan bu karma yaş grubunda yapılacak eğitimin kalitesi hem çocuklar hem anne babalar hem de öğretmenler açısından tatmin edici olmamaktadır. Nitekim literatürdeki bilgiler de bu sonucu desteklemektedir. Can ve Kılıç (2019), anasınıflarında farklı yaş gruplarının bulunmasının eğitimin 
kalitesini bozduğunu belirtmektedir. Akbaşlı ve Üredi (2014) tarafından yapılan araştırmada ilkokul birinci sınıf öğretmenleri, okula başlama yaşının öne alınmasıyla karma yaş grupları oluştuğunu, çocukların ince motor kaslarını kullanmada yeterli gelişime sahip olmamaları ve okuma yazma sürecinde yaşanan aksaklıklar gibi sorunlar yaşadıklarını belirtmişlerdir. Cerit ve diğerleri (2014)'nin yaptığı araştırmada; okul yöneticileri ve öğretmenler 4+4+4 eğitim sistemi ile ilgili en önemli sorunun "okula başlama yaşının küçülmesi” olduğunu belirtmişlerdir. Okula başlama yaşının küçülmesiyle; okula ve ortama uyum sağlayamama, farklı yaş gruplarının aynı sınıfta eğitim almak durumunda kalmasına bağlı olarak bireysel farklılıkların ve gereksinimlerin artması, programın uygulanabilirliği noktasında zorlukların ortaya çıkması, kalem tutma gibi ince motor becerilerde zorluklar, dinleme-okuma-yazma ve anlama güçlüklerinin artması, dikkat eksikliği, yönergeyi takip edememe ve verilen görevi yerine getirememe, fiziksel yetersizlikler, tuvalet ihtiyacının uygun şekilde karşılanamaması, birinci sınıflarda farklı yaş gruplarının oluşması gibi sorunların ortaya çıktığı ifade edilmiştir.

Araştırmaya katılan anasınıfı öğretmenleri ve ilkokul yöneticileri genel olarak 4+4+4 eğitim sisteminde sorunlar yaşamakla birlikte bu sorunların çözümüne yönelik önerilerde bulunmamışlar veya ilgisiz cevaplar vermişlerdir. Diğer taraftan yaşadıkları sorunlara ilişkin çözüm önerisi sunan katılımcılar tarafından ilkokul eğitiminin 5 yıl olması ve ilkokula ve dolayısıyla da ortaokula başlama yaşının erken olmaması gerektiği vurgulanmıştır. Türk aile yapısında çocukların koruyucu anne-babalık tutumuyla yetiştirilmesinin yaygın olduğu; ilkokul öğretmenlerinin anne-baba şefkatiyle çocuklara yaklaştığı, çocukların da ilkokul öğretmenini bir anne-baba gibi sahiplendiği gerçeği göz önünde bulundurulduğunda ilkokulun 5 yıl olmasının pedagojik açıdan daha uygun olduğu düşünülmektedir. Araştırma sonuçlarına göre; okula başlama yaşının çocukların gelişimsel özellikleri göz önünde bulundurularak veli, okul yönetimi, sınıf öğretmeni ve rehber öğretmenin dâhil olduğu bir komisyonla karara bağlanması gerekmektedir. Ayrıca okul öncesi eğitimin zorunlu eğitim kapsamına dâhil edilmesi ve bu süreçte çocukların yeteneklerine ve gelişim özelliklerine göre (yaş gruplarına) gruplanmasının yeni eğitim sisteminin sorunlarının çözüme kavuşturulmasında önemli olduğu görülmektedir. Külekçi (2013)'nin araştırmasında birleştirilmiş sınıflarda eğitim yapılan köy okullarındaki çocuklar açısından çocukların ilkokula erken yaşta başlamasının ve birinci sınıf müfredatının hafifletilmesinin çocukların okulla erken tanışması ve okula uyum sağlamaları açısından olumlu bir gelişme olduğu belirtilmiştir. Külekçi (2013)'nin araştırması bu yönüyle mevcut araştırma bulgularıla farklılık göstermektedir. Sınıf mevcudunun şehir merkezlerindeki okullara göre çok daha az olduğu köy okullarında, karma yaş gruplarından oluşan sınıflardaki dezavantajlar tolere edilebilir olarak düşünülebilir. Ancak aynı şeyi şehir merkezlerindeki kalabalık sınıflar için söylemek mümkün değildir. İlkokullar bünyesindeki anasınıflarında sınıf mevcuduna oranla fiziksel alanın yetersiz olduğu, bahçe-açık oyun alanı gibi açık hava alanlarının varlığı halinde bile kullanımının sınırlı olduğu bilinmektedir. Ayrıca anasınıflarında temizlik personeli ve yardımcı öğretmen gibi destek elemanlarının yetersiz olduğu bilinmektedir. Bu durum özellikle özbakım becerilerinin karşılanması konusunda sorun yaşayan daha küçük yaş grubundaki çocuklar açısından sorunlar meydana getirmektedir. Külekçi (2013)'nin araştırmasındaki katılımcıların bir kısmı da mevcut araştırma bulgularıyla benzer şekilde birinci sınıflarda okula başlama yaşının küçülmesi sonucunda 60-66 ay ve 67 ay ve üzeri şeklinde iki grup oluştuğunu ve birinci grubun temel ihtiyaçlarını dahi karşılayamadığını bu durumun da öğretmene ek bir bakım yükü getirdiğini belirtmiştir. Ayrıca 72 ay civarı çocuklara göre hazırlanan etkinliklerin küçük yaş grubundaki çocuklara zor geldiği için ilgilerini çekmediğini ya da küçük yaş grubuna göre hazırlanan etkinliklerin kolay geldiği için diğer grubun ilgisini çekmediğini, 60 aylık çocukların okula kabulü ve uyum konularında sorunlar yaşadıklarını dile getirmişlerdir. Memişoğlu ve İsmetoğlu (2013)'nun araştırma bulguları da yeni eğitim sistemiyle birlikte farklı yaş gruplarının bir arada eğitim alma zorunluluğunu getirdiğini ve bu durumun uyum sorunları oluşturduğunu göstermektedir. Literatürdeki bu bulgular ışı̆̆ında okul öncesi eğitimin zorunlu eğitimin sistemine dahil edilmesi ve zorunlu okul öncesi eğitim yaşının altında kalacak yaş grupları için de yaygınlaştırılması çalışmalarının ilkokula hazırlık ve uyum sorunlarının çözülmesinde tek ve en etkili yol olarak görülmektedir. Bilindiği gibi ilkokula başlama yaşı Temmuz 2019 tarih ve 30827 sayılı resmi gazetede yayımlanan Resmi Gazete (2019), Okul Öncesi ve İlköğretim Kurumları Yönetmeliği'nde Değişiklik Yapılmasına Dair Yönetmelik'te yapılan değişiklikle eylül ayı sonu itibari ile 69 ayını dolduran çocuklar ilkokula başlar, ancak velisinin izni olan 66, 67, 68 aylık 
çocuklar da ilkokula başlayabilir şeklinde değiştirilmiştir. Buna rağmen bu araştırmadaki bulgular öğretmenler tarafından okula başlama yaşının erken olarak değerlendirildiği yönündedir. Mevcut araştırmanın kimi bulguları literatürdeki araştırmalara göre yaşanan sorunlar ve çözüm önerileri açısından farklılıklar sunmaktadır. Bu durum, bu araştırmanın daha güncel görüşleri sunması literatürdeki araştırmaların ise eğitim sisteminin uygulanmaya başladığı ilk yıllarda yapılmış olmasından kaynaklanabilir. Örneğin ilkokulun 5 yıl olması gerektiği görüşünün literatürdeki araştırmalarda (Külekçi, 2013; Eğitim-BirSen, 2013; Memişoğlu ve İsmetoğlu, 2013) yer almazken, bu araştırmada çoğunlukla dile getirilmesi 4+4+4 eğitim sisteminin uygulanmaya başlamasından bu yana edinilen deneyimlerin bunu bir gereklilik olarak ortaya koymuş olabileceği düşünülmektedir. Araştırmada yaşanan sorunlara ilişkin önerilerin çözümler arasında meslek edinme ve mesleğe yönlendirme yapılabilmesi için lisenin zorunlu eğitim kapsamından çıkarılarak bu konuda serbestlik sağlanması ve 5+3 şeklindeki kesintisiz eğitime geri dönülmesi gerektiği de sıklıkla vurgulanmaktadır. Araştırma bulgularıyla paralel olarak Karakaş ve Erginer (2020) yaptığı araştırmada, 4+4+4 eğitim sisteminin gelişi ile birlikte erken yaşta mesleki ve teknik eğitime yönlendirme konusunda bir kargaşa yaşandığını, bu durumun teknik eğitim açısından öğrenci seçmede geç kalınmasıyla sonuçlandığını belirtmektedir.

Araştırma sonucuna göre; $4+4+4$ eğitim sisteminin okul öncesi eğitim sürecini etkileyen yönlerine ilişkin olarak katılımcıların çoğunluğu etkisi olmadığını belirtirken, ilkokula erken başlama, karma yaş grubu oluşması, bahçe, tuvalet gibi ortak fiziki alanların kullanımı açısından etkilediği ortaya çıkmıştır. Milli Eğitim Bakanlığı (2012) tarafından 4+4+4 eğitim sistemine yönelik eleştirilerin değerlendirildiği bir çalışmada, sekiz yıllık kesintisiz eğitimde birinci sınıf öğrencileri ile sekizinci sınıf öğrencisinin aynı bahçeyi, aynı tuvaleti ve aynı kantini kullanmak zorunda kaldıkları belirtilerek; daha büyük öğrencilerin bedensel üstünlükleri karşısında küçük öğrencilerin ezilebildiği ve ortak mekânlardan yeterince yararlanamadıkları, yeni sistemle birlikte ilkokul ve ortaokullarda yaş aralığının küçültülmesi sonucunda farklı binalarda eğitimler yapılması yoluyla bu sorunların önüne geçildiği ifade edilmiştir (MEB, 2012b). Memişoğlu ve İsmetoğlu (2013)'nun araştırmasında da ilkokul ve ortaokul binalarının fiziki olarak ayrılmasının küçük çocuklar açısından getirdiği rahatlama ifade edilmiştir. Literatürdeki bu bilgilerin mevcut araştırmanın sonuçlarıyla benzer olduğu görülmektedir. 4+4+4 eğitim sistemi ile birlikte ilkokul ve ortaokul binalarının ayrılması hem ilkokulun birinci, ikinci sınıf gibi küçük sınıfları hem de anasınıflarındaki çocuklar açısından olumlu bir gelişme olarak kabul edilmektedir. Araştırmada bazı ailelerin 12 yıllık zorunlu eğitim sürecini uzun bularak okul öncesi eğitime göndermek istemedikleri de bulunmuştur. Bu sonuç, ailelerin okul öncesi eğitim konusunda hala yeterli bilgi ve farkındalığa sahip olmadıklarını göstermektedir. Can ve Kılıç (2019)'ın araştırmasında bu sonuç "velinin okul öncesi eğitimin öneminin farkında olmaması, velinin ilgisiz olması" gibi bulgularla desteklenmektedir. Araştırmanın bir diğer önemli sonucuna göre; yeni eğitim sisteminin yürürlüğe girmesiyle okul öncesi eğitimin zorunlu eğitim kapsamına alınması projesinin geri plana atıldığı/olumsuz etkilendiği ortaya çıkmıştır. AÇEV ve ERG (2013) tarafından hazırlanan raporda da bu hususa dikkat çekilmiştir. Milli Eğitim Bakanlığı'nın okul öncesi eğitimde ulaşmayı hedeflediği \%100 okullaşma oranını yakalamak için daha fazla çaba sarf etmesi ve yaptırım uygulaması gerektiği belirtilmiştir. Bugün gelinen noktada 66-72 aylık çocuklara okul öncesi eğitim kurumlarda öncelik verildiği, ancak okullaşma oranının hala 3-5 yaş grubunun \% 41,8'lerde (TÜİK, 2020) olduğunu bilinmektedir. Oysa okul öncesi eğitime yapılan yatırımın, toplumsal geleceğimize yapılan en karlı yatırım olduğu bilinmelidir.

Araştırmada 4+4+4 eğitim sisteminde okul öncesi eğitim veya anasınıflarına yönelik yapılabilecek değişiklikler/düzenlemeler arasında okula başlama yaşında değişiklik yapılması gerektiği bulunmuştur. Laçin-Şimşek ve Öztuna-Kaplan (2020), okula başlama yaşının ülkeden ülkeye değiştiğini ve bu konudaki tartışmaların devam etmekle birlikte dünya genelinde kabul gören okula başlama yaşının 6 yaş (72 ay) olduğunu belirtmektedir. Mevcut araştırma sonucuna göre okula başlama yaşının en az 72 ay olması gerekmektedir. Bazı ülkelerde okul öncesi eğitim, zorunlu eğitim kapsamında yer aldığı için daha erken okula başlama yaşı uygulanmaktadır. Bazı ülkelerde ise zorunlu eğitim, ilkokul eğitimi ile birlikte başlamaktadır (Laçin-Şimşek ve Öztuna-Kaplan, 2020). Bu durum, araştırma sonucuna göre Türk Eğitim Sistemi açısından şu zorunluluğu ortaya çıkarmıştır. Erken okula başlama yaşının uygulandığı $4+4+4$ eğitim sisteminde mutlaka okul öncesi eğitim zorunlu eğitim kapsamına alınmalıdır. Başaran ve Güçlü (2020) tarafından yapılan 
araştırmada hangi eğitim kademesinin zorunlu olması gerektiği sorusuna öğretmenlerin tamamı ilkokulun zorunlu olması gerektiğini söylemiştir. Bunun yanı sıra okul öncesi eğitimden yararlanan veya yararlanmayan çocuklar arasındaki kıyaslamayı çok iyi yapabilecek konumda olan sınıf öğretmenleri, anasınıfı eğitiminin de zorunlu olması gerektiğini belirtmiştir. Bu araştırmada da katılımcıların yarısı okul öncesi eğitimin zorunlu olması gerektiğini belirtmiş ve bunu araştırmada sorulan her soruda belirtmiştir. Araştırmada okul öncesi eğitime yönelik yapılabilecek düzenlemelerle ilgili küçük bir katılımcı grubu tarafından herhangi öneride bulunulmadığı ve cevap verilmediği görülmekle birlikte; katılımcıların çoğunluğu tarafından okul öncesi eğitimde kaliteyi artırıcı planlamalar, veli ve yöneticilerin yanı sıra farklı kesimlerden de destek faaliyetleri, anasınıflarının yaş gruplarına uygun olarak gruplanması, okul öncesi eğitimin tüm kesimler tarafından daha ulaşılabilir olması, okul öncesi eğitim müfredatına yönelik değişiklikler yapılması gibi düzenlere ve değişikliklere ihtiyaç duyulduğu ortaya çıkmıştır. Karademir ve Akman (2021), bütün çocukların kaliteli okul öncesi eğitim hizmetlerinden fırsat eşitliği sağlanarak yararlandırılması gerektiğini belirterek; okul öncesi eğitimde kaliteli bir eğitim sürecinin unsurlarını; fiziki ortam ve kullanılacak materyalin yanında öğretmen yetkinliği, sınıfın kalabalık olup olmaması, öğretmen ile çocuk arasındaki iletişimin niteliği, uygulanacak programın uygunluğu, sağlıklı okul-öğretmen- veli iletişimi ve etkin ebeveyn katılımı olarak belirtmektedir. $\mathrm{Bu}$ araştırmada da Karademir ve Akman (2021) ile benzer şekilde kaliteli okul öncesi eğitim sürecinin bir parçası olan müfredat, ulaşılabilirlik, yaş grupları, destek hizmetleri gibi unsurların geliştirilmeye ihtiyacı olduğu ve okul öncesi eğitim daha nitelikli bir hale getirilmesi gerektiği ortaya çıkmıştır.

\section{Sonuç ve Öneriler}

Araştırma sonucunda; okul öncesi eğitimin zorunlu eğitim sürecine dâhil edilerek 4+4+4 eğitim sisteminin içinde yer alması gerektiği, ilkokul süresinin öğrencilerin gelişimine sağladığı olumlu katkılar göz önünde bulundurularak 5 yıl olarak uygulanmasının gerekliliği ortaya çıkmıştır. Yeni eğitim sisteminin uygulanmasıyla birlikte; farklı yaş aralığındaki (5-14 yaş gibi) çocukların ilköğretim okulları yerine ilkokul ve ortaokul olarak ayrılmış binalarda eğitim alarak okul bahçesi, tuvalet ve diğer ortak alanları kullanmak zorunda kalmadıkları böylece oluşabilecek ergen zorbalığının engellendiği ortaya çıkmıştır. $4+4+4$ eğitim sisteminin 12 yıllık zorunlu eğitim sürecini getirmesi ile birlikte toplumsal eğitim seviyesinin yükselmesine katkı sağlayacağı bulunmuştur. 12 yıllık zorunlu eğitim sisteminin gelişiyle okutulmayan kız çocukları açısından da eğitime devam etme şansı doğmuştur. Araştırmada altyapı eksiklikleri ve diğer hazırlıklar yapılmadan eğitim sisteminde değişikliğe gidilmesinin, sistemin geneline ilişkin olumsuz bir algı oluşturduğu bulunmuştur. İlkokula erken başlama nedeniyle anasınıflarında; daha küçük çocukların gelmesi ve ilkokul eğitimini bir yıl erteleyenlerin oluşturduğu karma yaş grubunun oluştuğu bunun sonucunda eğitim uygulamalarında aksaklıklar yaşandığı ortaya çıkmıştır. Çocukların ilkokula daha erken başlaması ve ilkokulun 4 yıla inmesi nedeniyle normalden yaklaşık 2 yıl kadar önce ortaokula başlandığı, bu durumunda henüz soyut işlemler dönemine geçmemiş çocuklar açısından okula uyum ve eğitim hayatına devam etmeme, akademik başarısızlık gibi sorunlar oluşturabileceği öngörüsü ortaya çıkmıştır. Lise eğitimin zorunlu eğitim sürecine dahil olması nedeniyle; okula devam etmek istemeyen çocukların uyumsuz okul davranışları nedeniyle diğer öğrenciler açısından olumsuz örnek oluşturduğu ve lise eğitiminden sonra çıraklık ve kalfalık yapacak çocuk bulunmamasının bazı meslekler açısından sorunlar oluşturduğu bulunmuştur. Araştırmada ayrıca ilkokula başlama yaşının en az 72 ay olarak uygulanması gerektiği, ilkokul öncesi okul öncesi eğitimin/anasınıfı eğitiminin zorunlu olması ve daha küçük yaş grupları için okul öncesi eğitimin yaygınlaştırması ve tüm kesimlerce ulaşılabilir olmasının gerekliliği ortaya çıkmıştır. Son olarak anasınıflarına alandan yönetici atanarak, müfredat değişiklikleri yapılarak, materyal desteği sağlanarak, öğretmenlere hizmet içi eğitimler sunularak ve yeterli sayıda yardımcı öğretmen ve temizlik personeli sağlanarak okul öncesi eğitim sürecinin güçlendirilmesi gerektiği ortaya çıkmıştır.

Araştırma sonuçları okul öncesi eğitim açısından özetlenecek olursa; ilkokula başlama yaşının küçülmesi sonucunda anasınıflarına gelen çocukların yaş grubunun küçülmesi ve rapor alarak ilkokula başlamayanların bir arada bulunmasıyla oluşan karma yaş gruplu sınıflarda farklı gelişimsel özelliklere sahip çocuklar bir arada eğitime devam etmek zorunda kalmaktadır. Bu durum, çocuklar açısından okula uyum sağlayamama, özbakım becerilerinde ve ince motor becerilerde yetersizlik gibi sıkıntılara, yardımcı personelin olmadığı 
sınıflarda öğretmenler açısından da eğitim faaliyetleri yerine çocukların özbakımlarıyla ilgilenme gibi ek yükümlülüklere neden olmaktadır. Yeni eğitim sistemi ile beraber okul öncesi eğitimin zorunlu eğitim kapsamına alınması projesinin gerçekleştirilemediği, okul öncesi eğitimin geri plana itildiği ve okul öncesi eğitimde kalitenin düştüğü belirlenmiştir. Araştırmanın sonuçları doğrultusunda şu öneriler sunulmuştur:

1. Okul öncesi eğitim, zorunlu eğitim sistemine dahil edilmeli ve özellikle ilkokula başlayacak çocukların anasınıfı eğitiminden yararlanması sağlanarak okula hazırbulunuşluk düzeyleri yükseltilmelidir,

2. Anasınıflarında karma yaş grubunun oluştuğu durumlarda, çocuklar yaş gruplarına uygun olarak sinıflara ayrılmalı ve eğitimlerin gelişimsel seviyelerine uygun olarak sunulmasına özen gösterilmelidir,

3. Karma yaş gruplarının ayrı sınıflarda eğitim almasının mümkün olmadığı durumlarda yardımcı öğretmen ve yardımcı temizlik personeli desteği sağlanarak anasınıfı öğretmenlerinin sadece çocukların eğitim çalışmalarına odaklanmasına imkân sağlanmalıdır,

4. Literatürdeki benzer araştırmalarda olduğu gibi bu araştırmada da okula başlama yaşının erkene alınmasının birçok zorluğa neden olduğu belirlenmiştir. Bu konu, gelişim psikologları ve politika yapıcılar tarafından dünya devletlerindeki örnekler incelenerek yeniden gözden geçirilmelidir,

5. İlkokullar ve ortaokullar bünyesindeki anasınıflarındaki çocukların kullanacağı ortak alanların ve bahçenin genel ortak alandan ve bahçeden ayrı olarak planlanması gerekmektedir,

6. $4+4+4$ eğitim sisteminin meydana getirdiği yeni durumlara uyum sağlamak için okul öncesi eğitim müfredatında yenilikler/ değişiklikler/ düzenlemeler yapılmalıdır,

7. İsteyen öğrenciler için, lise eğitiminin çıraklık/kalfalık kurumlarıyla koordineli şekilde yürütülmesi sağlanabilir,

8. Araştırma, 4+4+4 eğitim sistemine ilişkin karşılaşılan sorunların ve çözüm önerilerinin belirlenmesi için farklı demografik özelliklere sahip daha büyük örneklemlerle yenilebilir,

9. İlkokul birinci sınıf öğretmenleri ile anasınıfı öğretmenlerinin $4+4+4$ eğitim sistemine ilişkin görüşlerinin karşılaştırmalı olarak incelendiği araştırmalar yapılabilir,

10. Çocuğu anasınıfında ve ilkokul birinci sınıfta olan velilerin yeni eğitim sistemine ilişkin görüşlerine yer verilen araştırmalar yapılabilir.

\section{Yazarın Beyanı}

Araştırmacıların katkı oranı beyanı: Araştırmanın tüm aşamaları araştırmacı tarafından gerçekleştirilmiştir.

Etik Kurul Kararı: Aksaray Üniversitesi Etik Kurulu Komisyonu'nun 2021/04-93 numaralı kararınca araştırmanın etik ilkelere uygun olduğu belirtilmiştir.

Çatışma beyanı: Araştırmacı herhangi bir kişi veya kurum ile çıkar çatışması içerisinde değgildir.

Destek ve teşekkür: Araştırmaya katılan anasınıfı öğretmenleri ve ilkokul yöneticilerine değerli görüşlerini paylaşarak katkıda bulundukları için teşekkürlerimi sunuyorum.

\section{Kaynaklar}

Akbaşlı, S. \& Üredi, L. (2014). Eğitim sistemindeki 4+4+4 yapılanmasına ilişkin öğretmen görüşleri. Journal of Teacher Education and Educators, 3(1), 109-136.

Ankara Üniversitesi (2012). Ankara Üniversitesi Eğitim Bilimleri Fakültesi'nin 222 sayılı İlköğretim ve Eğitim Kanunu ile Bazı Kanunlarda Değişiklik Yapılmasına Dair Kanun Teklifi'ne İlişkin Görüşü. 06.05.2021 tarihinde $\quad$ http://www.ankder.org.tr/444-sistemi-hakkinda-egitim-bilimleri-fakultesinin-gorusu/ adresinden alınmıştır.

Anne Çocuk Eğitim Vakfı (AÇEV) ve Eğitim Reformu Girişimi (ERG), (2013). Erken Çocukluk Eğitimi ve 4+4+4 Düzenlemesi. Politika Raporu, İstanbul.

Arı, A. (2014). İlkokul birinci sınıfa başlama yaşına ilişkin öğretmen görüşleri. Kuram ve Uygulamada Ĕgitim Bilimleri, 14(3), 1031-1047. 
Aslan, M. (2014). 60-72 aylık çocukların ilkokula başlama durumlarının incelenmesi (Yayımlanmamış Yüksek Lisans Tezi). Fırat Üniversitesi, Elazı $\breve{g}$.

Aybek, B., \& Aslan, S. (2015). Ortaokul öğretmenlerinin 4+4+4 kesintili zorunlu eğitim sistemine yönelik yaşadığ1 sorunlar (Elazı̆̆ İli Örneği), İlköğretim Online, 14(2), 770-786.

Aykaç, N., Kabaran, H., Atar, E., \& Bilgin, H. (2014) İlkokul birinci sınıf öğrencilerinin 4+4+4 uygulaması sonucunda yaşadıkları sorunların öğretmen görüşlerine dayalı olarak değerlendirilmesi (Muğla ili Örneği). Turkish Studies, 9(2), 335-348.

Ayre, C., \& Scally, A. J. (2014). Critical values for lawshe's content validity ratio: revisiting the original methods of calculation. Measurement and Evaluation in Counseling and Development, 47(1) 79-86.

Aytaçlı, B., \& Gündoğdu, K. (2018). 4+4+4 ile ilk defa 5. sınıf derslerine giren matematik öğretmenlerinin sürece ilişkin görüşleri. Adnan Menderes Üniversitesi Ĕ̆itim Fakültesi Eğitim Bilimleri Dergisi, 9(1), 12-30.

Bahtiyar-Karadeniz, C. (2012). Öğretmenlerin 4+4+4 zorunlu eğitim sitemine ilişkin görüşleri. Ĕ̆gitim Bilim Toplum Dergisi, 10(40), 34-53.

Baltacı, A. (2019). Nitel araştırma süreci: Nitel bir araştırma nasıl yapılır?. Ahi Evran Üniversitesi Sosyal Bilimler Enstitüsü Dergisi, 5(2), 368-388.

Başaran, B. P. (2016). 4+4+4 eğitim sisteminde yöneticilerin ve öğretmenlerin karşılaştığı sorunlar (Yayımlanmamış Yüksek Lisans Tezi). Gazi Üniversitesi, Ankara.

Başaran, M., \& Güçlü, F. (2020). İlkokullarda hangi derslere hangi öğretmenlerin girmesi gerektiğine ilişkin öğretmen görüşleri. Türkiye Ĕ̆itim Dergisi, 5(2), 444-459.

Başaran, M., Dursun, B., Gür Dortok, H. D., \& Yılmaz, G. (2021). Evaluation of preschool education program according to cipp model. Pedagogical Research, 6(2), 91.

Bayat, S. (2015). İlk okuma yazma öğretiminde 60-66 aylık çocuklar ile ilgili yaşanan güçlüklere ilişkin öğretmen görüşleri. Uluslararası Türk Ĕ̆itim Bilimleri Dergisi, 4, 172-185.

Boğaziçi Üniversitesi (2012). 5.1.1961 tarih ve 222 sayılı İköğretim ve Eğitim Kanunu ile Bazı Kanunlarda Değişiklik Yapılmasına Dair Kanun Teklifi Hakkında Boğaziçi Üniversitesi Eğitim Fakültesi'nin Güncellenen Görüşü. 06.05.2021 tarihinde https://fed.boun.edu.tr/tr/bogazici-universitesi-egitim-fakultesinin-guncellenengorusu adresinden alınmıştır.

Boz, T., \& Yıldırım, A. (2014). 4+4+4 eğitim sisteminde birinci sınıf öğretmenlerinin karşılaştığı zorluklar. Başkent Üniversitesi Eğitim Fakültesi Dergisi, 1(2), 54-65.

Büyüköztürk, Ş., Kılıç Çakmak, E., Akgün, Ö., Karadeniz, Ş., \& Demirel, F. (2009). Bilimsel Araştırma Yöntemleri. Ankara: Pegem Akademi.

Can, E., \& Kılıç, Ş. (2019). Okul öncesi eğitim: temel sorunlar ve çözüm önerileri. Milli Eğitim (Özel Sayı), 48(1), 483-519.

Cansoy, R. (2018). Uluslararası çerçevelere göre 21. yüzyıl becerileri ve eğitim sisteminde kazandırılması, İnsan ve Toplum Bilimleri Araştırmaları Dergisi, 7(4), 3112-3134.

Cerit, Y. Akgün, N., Yıldız, K., \& Soysal, M. R. (2014). Yeni eğitim sisteminin (4+4+4) uygulanmasında yaşanan sorunlar ve çözüm önerileri (Bolu ili örneği). Eğitim Bilimleri Araştırmaları Dergisi, 4(1), 59-82.

Creswell, J. (2013). Nicel, Nitel Ve Karma Yöntem Yaklaşımları, Araştırma Deseni, Çeviri Ed., Selçuk Beşir Demir, Ankara: Eğiten Kitap Yayınları.

Dağ, M. (2017). Farklı yaşlarda ilkokula başlayan çocukların akademik başarı ve sosyal beceri düzeylerinin karşılaştırılması (Yayımlanmamış Yüksek Lisans Tezi). Uşak Üniversitesi, Uşak.

Dirlik, C. (2014). 4+4+ 4 eğitim sisteminde 60-66 aylı öğrencilerin okula hazırbulunuşlukta sosyal uyum düzeylerinin 
Anasınıfı Öğretmenleri ve İlkokul Yöneticilerinin ...

incelenmesi (Yayımlanmamış Yüksek Lisans Tezi). Aydın Üniversitesi-Yıldız Teknik Üniversitesi, İstanbul.

Doğan, S., Demir, S., \& Pınar, M. (2014). 4+4+4 kesintili zorunlu eğitim sisteminin sınıf öğretmenlerinin görüşleri doğrultusunda değerlendirilmesi. İlköğretim Online, 13(2), 503-517.

Doğan, S., Uğurlu, C. T., \& Demir, A. (2014). 4+4+4 eğitim sisteminin okul paydaşlarına olumlu ve olumsuz etkilerinin yönetici görüşlerine göre incelenmesi. Gaziantep University Journal of Social Sciences, 13(1), 115138.

Durmaz, G. (2020). Illkokula başlama yaşına ilişkin yönetici ve öğretmen görüşleri (Tezsiz Yüksek Lisans Projesi). Pamukkale Üniversitesi, Denizli.

Durmuş̧̧elebi, M., \& Bilgili, A. (2014). Yeni (12 yıllık) eğitim sistemi, karşılaşılan sorunlar ve dünyadaki uygulamalardan bazılarınin incelenmesi. Turkish Studies - International Periodical For The Languages, Literature and History of Turkish or Turkic, 9(2), 603-621.

Eğitim Reformu Girişimi- ERG, (2012). 4+4+4'e Geçiş, Eylül 2012 Bilgi ve Politika Notları. İstanbul. 10.05.2021 tarihinde https://www.egitimreformugirisimi.org/444e-gecis-bilgi-ve-politika-notlari-yayimladi/ adresinden alınmıştır.

Eğitimciler Birliği Sendikası (Eğitim-Bir-Sen), (2013). 4+4+4 Eğitim Reformunu İzleme Raporu, Eğitimciler Birliği Sendikası, Ankara. 16.05.2021

Epçaçan, C. (2014). İlkokul ve ortaokul öğretmen ve yöneticilerinin 4+4+4 eğitim sistemine ilişkin görüşleri (Siirt ili örneği). EKEV Akademi Dergisi, 18(58), 505-522.

Gedik, S. (2015). Öğretmen algılarına göre 60-66 aylık çocuklarda okula uyumun incelenmesi (Fatih İlçesi Örneği) (Yayımlanmamış Yüksek Lisans Tezi). Yeditepe Üniversitesi, İstanbul.

Güven, İ. (2012). Eğitimde 4+4+4 ve fatih projesi yasa tasarısı = reform mu? İlköğretim-Online, 11 (3), 556-577.

Hacettepe Üniversitesi, (2012). Hacettepe Üniversitesi Senatosu'ndan "4+4+4" Eğitim Düzenlemesiyle İlgili Olarak Kamuoyuna Açılama. 06.05 .2021 tarihinde https://www.hacettepe.edu.tr/duyuru/rekduy/zorunluegitimbasin.pdf adresinden alınmıştır.

Hareket, E., Erdoğan, E., \& Dündar, H. (2016). Türk Eğitim Sistemine ilişkin bir durum çalışması. Eğitim ve Öğretim Araştırmaları Dergisi, 5(1), 287-299.

Kara, M. (2020). Eğitim paydaşlarının görüşleri doğrultusunda Türk Eğitim Sisteminin sorunları. Kırşehir Ĕ̆itim Fakültesi Dergisi, 21(3), 1650-1694.

Karademir, A., \& Akman, B. (2021). Farklı bakış açılarıyla okul öncesi eğitimde kalite unsurları: Nitel bir araştırma. Cumhuriyet International Journal of Education, 10(1), 181-206.

Karakaş, M., \& Erginer, E. (2020). İlköğretim öğrencilerini mesleki-teknik eğitim sistemine yönelik alg1 düzeyleri, Uluslararası Sosyal Bilimler Ĕ̆itimi Dergisi, 6(2), 238-2258.

Külekçi, E. (2013). 4+4+4 eğitim sistemi kapsamında birleştirilmiş sınıf uygulamasına ilişkin öğretmen görüşlerinin değerlendirilmesi. Eğitim ve Öğretim Araştırmaları Dergisi, 2(2), 369-377.

Laçin-Şimşek, C., \& Öztuna-Kaplan, A. (2020). Science teachers' opinions about 5th grade students and their science teaching experiences after 4+4+4 system. International Journal of Psychology and Educational Studies, $7(3), 111-125$

Lawshe, C. H. (1975). A quantitative approach to content validity. Personnel Psychology, 28, 563-575.

Memişoğlu, S. P., \& İsmetoğlu, M. (2013). Zorunlu eğitimde 4+4+4 uygulamasına ilişkin okul yöneticilerinin görüşleri. Eğitim ve Öğretim Araştırmaları Dergisi, 2(2), 14-25.

Milli Eğitim Bakanlığı -MEB (2012a). 09.05.2012 Tarihli "12 Yıllık Zorunlu Ĕ̆itime Yönelik Uygulamalar" Konulu, B.08. 0. ÖKM. 0.00-00.00/401 Sayıl Genelge. 13.05.2021 tarihinde 
Songül GİREN

http://mebk12.meb.gov.tr/meb iys dosyalar/06/27/851665/dosyalar/2015 06/15091240 genelge.docx adre sinden alınmıştır.

Milli Eğitim Bakanlığı- MEB (2012b). 12 Yll Zorunlu Ĕ̆itim Sorular- Cevaplar. Ankara. 13.05.2021 tarihinde http://www.meb.gov.tr/duyurular/duyurular2012/12Yil Soru Cevaplar.pdf adresinden alınmıştır.

Onat Kocabıyık, O. (2016). Olgubilim ve gömülü kuram: bazı özellikler açısından karşılaştırma. Trakya Üniversitesi Ĕ̆itim Fakültesi Dergisi, 6(1), 55-66

Ortadoğu Teknik Üniversitesi (ODTÜ), (2012). 5.1.1961 Tarih Ve 222 Sayılı İlköğretim ve Eğitim Kanunu ile Bazı Kanunlarda Değişiklik Yapılmasına Dair Kanun Teklifi Hakkında ODTÜ Eğitim Fakültesi İlköğretim Bölümü Görüşü. 07.05.2021 tarihinde http://fedu.metu.edu.tr/tr/system/files/ReportsAndDocuments/fakultegorusu/the faculty position on 4 44 second proposal in turkish.pdf adresinden alınmıştır.

Örs, Ç. Erdoğan, H., \& Kipici, K. (2013). Eğitim yöneticileri bakış açısıyla 12 yıllık kesintili-zorunlu eğitim sistemi-Iğdır örneği. Iğdır Üniversitesi Sosyal Bilimler Enstitüsü Dergisi, 4, 131-154.

Özarslan, N. (2014). Birinci sınıfta öğrenim görmekte olan (60-71 ve 72-84 aylık) öğrencilerin okul olgunluğu düzeyleri ve bu öğrencileri okutmakta olan öğretmenlerin gözlediği okula uyum ve sinıf yönetimi sorunları(Yayımlanmamış Yüksek Lisans Tezi). Okan Üniversitesi, İstanbul.

Özdemir, A., \& Battal, Ş. (2019). İlkokula erken yaşta başlayan öğrencilerin okula uyum süreci ve akademik başarı bağlamında yaşadıkları sorunlar. Uluslararası Toplum Araştırmaları Dergisi, 11(18), 1633-1683.

Patton, M. Q. (2014). Nitel Araştırma ve Değerlendirme Yöntemleri. (Çev: Mesut Bütün, Selçuk Beşir Demir Pegem Akademi) California: SAGE.

Pekdoğan, S., \& Karamustafaoğlu, S. (2015). 4+4+4 düzenlemesinin okul öncesi eğitim üzerindeki etkilerinin incelenmesi. Ahi Evran Üniversitesi Kırşehir Ĕ̆itim Fakültesi Dergisi (KEFAD) 16(2), 219-234.

T. C. Kalkınma Bakanlığı (2014). Eğitim Sisteminin Kalitesinin Artırılması. Onuncu Kalkınma Planı Özel İhtisas Komisyonu Raporu, Ankara.

T. C. Resmi Gazete (10 Temmuz 2019 Çarşamba tarihli (30827 sayılı). Millı̂ Ĕ̆itim Bakanlığı Okul Öncesi Ĕ̆itim ve Ilköğretim Kurumları Yönetmeliğinde Değişiklik Yapılmasına Dair Yönetmelik. 15.05.2021 tarihinde https://www.resmigazete.gov.tr/eskiler/2019/07/20190710-6.htm adresinden alınmıştır.

TEDMEM, 2017. Türkiye'de Erken Çocukluk Ĕ̆itimi Ve Bakımı: Mevcut Durum ve Öneriler, Tedmem Yuvarlak Masa. 20.07.2021 tarihinde https://tedmem.org/download/turkiyede-erken-cocukluk-egitimi-bakimimevcut-durum-oneriler?wpdmdl=2430\&refresh=613343fd008ae1630749692 adresinden alınmıştır.

Tekindal, M., \& Uğuz Arsu, Ş. (2020). Nitel araştırma yöntemi olarak fenomenolojik yaklaşımın kapsamı ve sürecine yönelik bir derleme. Ufkun Ötesi Bilim Dergisi, 20(1), 153-182.

Terzi, Ç. (2011). Türk Eğitim Sistemi'nde okulların örgüt ve yönetim yapısı ile yapılandırmacı eğitim yaklaşımı arasındaki ilişkinin çözümlenmesi. Anadolu Journal of Educational Sciences International, 1(1), 75-82.

Turan, T. (2018). 4+4+4 eğitim sisteminde 60-66 aylık çocukların okula erken başlamasının değgrlendirilmesi (Yüksek Lisans Tezi). Fırat Üniversitesi, Elazığ.

Tutal, Ö. (2013). Okuma-yazma öğrenmede okula başlama yaşının okuma-yazma başarısına etkisi (Yayımlanmamış Yüksek Lisans Tezi). Dicle Üniversitesi, Diyarbakır.

Türkiye İstatistik Kurumu (TÜIK), (2020). Öğretim Yılına Göre Okul Öncesinde Net Okullaşma Oranı, Okul, Öğrenci, Öğretmen ve Derslik Sayısı. 20.05.2021 tarihinde https://data.tuik.gov.tr/Kategori/GetKategori?p=egitim-kultur-spor-ve-turizm-105\&dil=1 adresinden alınmıștır.

Yıldırım, A., \& Şimşek, H. (2013). Sosyal Bilimlerde Nitel Araştırma Yöntemleri. Ankara: Seçkin Yayıncılık. 
Yılmaz, N. (2005). Türkiye'de okul öncesi eğitimi. Müzeyyen Sevinç (Ed.), Gelişim ve Eğitimde Yeni YaklaşımlarI içinde (s.12-17). İstanbul: Morpa Kültür.

Yoleri, S., \& Tanış, H. M. (2015). İlkokul birinci sınıf öğrencilerinin okula uyum düzeylerini etkileyen değişkenlerin incelenmesi. Karabük Üniversitesi Sosyal Bilimler Enstitüsü Dergisi, 4(2), 130-141. 
Songül GİREN

\section{EXTENDED ABSTRACT}

\section{Introduction}

Education plays the leading role in differentiation and change during the 21st century, also known as the century of knowledge. Alongside social, political, economic and technological transitions, people's expectations of more or different things from the education system of their countries have forced the leaders to make modifications to their education programs. Looking at Turkey's education system in recent history, it may be seen that, during the period of 2005-2006, to meet the expectations of a new model of societies, constructivism-based modifications were made to the primary school education system countrywide (Cansoy, 2018; Örs, Erdoğan and Kipici, 2013; Terzi, 2011). However, the assessment of this new constructivist education system shows that, "while examining the organization and management of school leadership, vision and culture, it may be understood that the new modified system has no visible effect in these categories. On the contrary, it is more likely to witness practices that contradict the constructivist approach." (Terzi, 2011)

During the school year of 2012-2013, the mandatory 8-year primary education program in Turkey, which involved the steps of primary school and middle school, was changed to a $4+4+4$-year plan, meaning a gradual 12-year compulsory education program. In this system, the first 4 years are primary school (grades 1-4), the second set of 4 years is middle school (grades 5-8), and the last 4 years constitute high school (grades 9-12) (MEB, 2012a). Furthermore, with this system, 60-month-old students have been forced to enroll in first grade and compete for success with peers with almost a 24-month age difference (Durmaz, 2020).

Several officials and representatives of education faculties at universities, non-governmental organizations, education unions, and organizations and institutions dealing with education have commented on the new modified education system. Analyzing these comments and opinions, especially the ones concerning preschool education, taking preschool out of mandatory education which is a disadvantage for students who come from a low-level socioeconomic background in terms of preparing for primary school, has a few consequences such as that students starting primary school one year earlier is not scientifically fitted for their growth, keeping in mind that childhood is a fast-paced growth period in all aspects and that teaching 6072-month-old students, who are mentally, physically, socially and emotionally different from each other, in the same environment is inconvenient and imposes additional responsibilities on the teacher (Ankara Üniversitesi, 2012; Boğaziçi Üniversitesi, 2012; ODTÜ, 2012).

\section{The Purpose of the Study}

The purpose of this study was to identify problems caused by the gradual $4+4+4$ mandatory education plan by interviewing kindergarten teachers and primary school administrators (principal and vice-principal) and propose solutions to these problems.

\section{Method}

This was a qualitative study. The sample consisted of 42 kindergarten teachers and primary school administrators (principal and vice-principal) who had 8 or more years of occupational experience in the city of Adana, district of Kozan, city of Osmaniye, district of Kadirli, and the city of Aksaray, Central district. The participants were selected based on their experience in the gradual $4+4+4$ mandatory education system, and a purposive sampling method was used. The data for this study were collected by using a form that consisted of standardized open-ended interview questions. The data were analyzed by using the steps of the context analysis method. The open-ended questions in the form were prepared under the guidance of 3 experts in the field. The questions in the form were as follows. 1) What are your thoughts on the new education system $(4+4+4)$ ? 2) What are the positive aspects of the new education system $(4+4+4)$ in your opinion? 3) What are the negative aspects (obstacles you faced) of the new education system $(4+4+4)$ in your opinion? 4) What are some solutions you would propose for the obstacles you have faced about the new education system $(4+4+4)$ ? 5) What are some effects of the new education system $(4+4+4)$ on preschool education and the kindergarten? 6) In your opinion, what type of changes should be made to the new education system $(4+4+4)$ ? Why?

The demographic characteristics of the sample were as follows: 1 (4.35\%) of the kindergarten teachers was 
male, while 22 (99.65\%) were female. The administrators of the primary schools were all male. Eight (42.11\%) of the administrators of the primary schools were vice-principals, and 11 (57.89\%) were principals. Among the participants, 3 (7.14\%) had graduated from Çukurova University, 6 (14.29\%) from Selçuk University, 1 (2.38\%) from Afyon Kocatepe University, 9 (21.43\%) from Anadolu University, 7 (16.67\%) from Gazi University, 1 (2.38\%) from Sakarya University, 3 (7.14\%) from Niğde University, 2 (4.76\%) from Mustafa Kemal University, 3 (7.14\%) from Atatürk University, 1 (2.38\%) from Karadeniz Technical University, 1 (2.38\%) from Uludağ University, 1 (2.38\%) from Kırşehir Ahi Evran University, 1 (2.38\%) from Malatya University, 1 (2.38\%) from Ağrı İbrahim Çeçen University, 1 (2.38\%) from 19 Mayıs University, and 1 (2.38\%) from Çanakkale 18 Mart University. While 19 (45.24) participants had 10-15 years of occupational experience, 7 (16.67\%) people had 1620 years of experience, $8(19.05 \%)$ had $21-25$ years of experience, and $8(19.05 \%)$ had over 26 years of experience.

\section{Results}

According to the results of this study in which 42 participants (23 kindergarten teachers and 19 primary school administrators) who have 10 to 36 years of experience were included, the effects of the $4+4+4$ mandatory education system may be classified in 6 themes pertaining to different keywords.

Theme 1: General thoughts on the education system. Keywords; positive, negative, scope, primary school period, and no comment.

Theme 2: Positive aspects of the education system. Keywords: no positive aspects, school period, being mandatory, school age, physical environment, female children, education period, and continuity.

Theme 3: Negative aspects of the education system. Keywords: groundwork missing, forcefully teaching, starting early, mixed-age groups, no negative aspects, education period, and occupational inclination.

Theme 4: Solutions proposed for the problems. Keywords: primary school should be extended to 5 years, being flexible on the age of starting school, occupational orientation, mandatory preschool education, not starting early, grouping, high school being optional, no solutions, and 8 years of education.

Theme 5: The effects of the education system on preschool. Keywords: no effects, starting primary school early, mixed-age groups, physical environment, not sending students to school, and mandatory preschool education.

Theme 6: Modifications to preschool education. Keywords: changing ages, compulsory preschool education, support, quality, age groups, syllabus, no advice, and accessibility.

\section{Conclusion}

The statements of the kindergarten teachers and primary school administrators were mostly about the complications of students starting primary school at a younger age and the difficulties of having students at different ages in the same classroom, as well as the mandatory preschool education project not being put through and being pushed back, and as an outcome, the quality of education decreasing. According to the results, pre-school education should be included in the $4+4+4$ compulsory education system, primary school should be implemented as 5 years, primary school should not be started at an early age (at 72 months old), the preschool education system should be supported in terms of the curricula, auxiliary personnel, field specialist managers, materials and the physical environment. Preschool education should be more accessible (free) for all children. According to the findings of this study, pre-school education has been pushed into the background with the $4+4+4$ education system. Therefore, development and dissemination efforts should be given importance. 